\title{
Flora do Espírito Santo: Meliaceae
}

\author{
Flora of Espírito Santo: Meliaceae
}

Thiago Bevilacqua Flores ${ }^{1,2,4}$, Vinicius Castro Souza ${ }^{2}$ \& Rubens Luiz Gayoso Coelho ${ }^{3}$

\begin{abstract}
Resumo
Meliaceae possui 50 gêneros e cerca de 550 espécies distribuídas em todo mundo, embora com maior diversidade na região pantropical. No Brasil, são encontradas 84 espécies distribuídas em sete gêneros. Esse estudo apresenta o tratamento florístico das espécies de Meliaceae no estado do Espírito Santo. Para alcançar esses resultados, foram consultados os principais herbários do país, além de realizadas atividades de campo. Os principais resultados deste trabalho incluem, descrições morfológicas para os gêneros e as espécies, chaves de identificação, ilustrações e comentários taxonômicos. Com relação as novidades taxonômicas, foram encontradas 25 espécies que pertencem a quatro gêneros, uma pertencente a Cabralea, duas a Cedrela, seis a Guarea e 16 a Trichilia. Nesse estudo também são apresentados uma nova ocorrência para o estado e ainda, duas espécies de Trichilia são provisoriamente tratadas como Trichilia sp. 1 e Trichilia sp. 2.

Palavras-chave: angiospermas, flora, Mata Atlântica, taxonomia.

Abstract

Meliaceae has 50 genera and about 550 species distributed in the whole world, although with greater diversity in the pantropical region. In Brazil, there are 84 species distributed in seven genera. This study presents the floristic treatment of the Meliaceae species in the state of Espírito Santo. In order to achieve these results, we consulted the main herbaria in the country and performed field activities. The main results of this work include the morphological descriptions of the genera and species, identification keys, illustrations and taxonomic comments. In terms of the taxonomic novelties, 25 species belonging to four genera were found: One belonging to Cabralea, two to Cedrela, six to Guarea, and 16 to Trichilia. In this study, we also present a new species occurrence for the state and therefore, the two Trichilia species are provisionally treated as Trichilia sp. 1 and Trichilia sp. 2.
\end{abstract}

Key words: angiosperms, flora, Atlantic forest, taxonomy.

\section{Introdução}

Meliaceae possui cerca de 550 espécies distribuídas em aproximadamente 50 gêneros. A família apresenta distribuição principalmente cosmopolita, mas sobretudo pantropical e ocorrendo em diversos habitats, desde florestas úmidas até ambientes semiáridos (Pennington \& Styles 1975; Mabberley et al. 1995). A região neotropical é o centro de diversidade da família, apresentando 122 espécies em oito gêneros. O continente africano e a região da Malásia, também são importantes regiões para a diversidade desse grupo (Pennington 1981; Mabberley et al. 1995). No Brasil, são encontradas 84 espécies distribuídas em sete gêneros: Cabralea A.Juss., Carapa Aubl., Cedrela P.Browne, Guarea F.Allam. ex L., Melia L. (subespontâneo), Swietenia Jacq. e Trichilia P.Browne. Meliaceae é encontrada em todos os estados do Brasil, contudo, o maior número de espécies é concentrado principalmente nos domínios fitogeográficos da Amazônia e da Mata Atlântica (BFG 2015).

\footnotetext{
${ }^{1}$ Universidade Estadual de Campinas, Inst. Biologia, Cidade Universitária Zeferino Vaz, R. Monteiro Lobato 255, Campinas, 13083-862, SP, Brasil.

${ }^{2}$ Universidade de São Paulo, Escola Superior de Agricultura "Luiz de Queiroz", Lab. Botânica Sistemática, Herbário ESA, Av. Pádua Dias 11, Bairro Agronomia, 13418-900, Piracicaba, SP, Brasil.

${ }^{3}$ Universidade de São Paulo, Escola de Artes, Ciências e Humanidades, R. Arlindo Bettio 1000, 03828-000, São Paulo, SP, Brasil.

${ }^{4}$ Autor para correspondência: tbflores@gmail.com
} 
Economicamente, merecem destaque algumas espécies que produzem madeira de boa qualidade para a indústria madeireira e moveleira, como os "mognos" (Swietenia spp.), as "canjeranas" (Cabralea canjerana (Vell.) Mart.) e os "cedros" (Cedrela spp.). Algumas espécies, também são cultivadas como ornamentais, como "aglaia" (Aglaia Lour. spp.), "árvore-de-Santa-Bárbara" (Melia azadirachta L.) e o "niim" (Azadirachta indica A. Juss.), que além disso, também apresenta uma substância chamada "azadiractina", utilizada como inseticida (Lorenzi et al. 2003; Souza \& Lorenzi 2010).

Meliaceae tem um longo histórico taxonômico que foi sumarizado na obra de Pennington \& Styles (1975). Os principais trabalhos que trataram a família de modo amplo, são os de De Candolle (1824); Hooker (1862); C. De Candolle (1878a); Harms $(1896,1940)$ e Pennington \& Styles (1975). Também é importante ressaltar, os trabalhos de Pennington (1981) e Mabberley et al. (1995) que trataram um grande número de espécies em regiões de importante diversidade para a família. Além disso, algumas revisões taxonômicas para os gêneros foram realizadas recentemente, como por exemplo, para a região neotropical, os gêneros Cedrela (Pennington \& Muellner 2010), Carapa (Kenfack 2011), Guarea (Pennington \& Clarkson 2013) e Trichilia (Pennington 2016) foram revistos nessa década.

Do ponto de vista da classificação, vale destacar os trabalhos de C. De Candolle (1878b) que dividiu a família em quatro tribos (Melieae, Trichilieae, Swietenieae e Cedreleae), os de Harms (1896 e 1940), que propuseram a divisão da família em três subfamílias (Cedreloideae, Swietenioideae e Melioideae) e o de Pennington \& Styles (1975), que dividiu a família em quatro subfamílias - Melioideae com sete tribos e 35 gêneros, Swietenioideae com três tribos e sete gêneros e Quivisianthoideae e Capuronianthoideae, com apenas um gênero cada. Muellner et al. (2003), através do uso de dados macromoleculares, indicam que Quivisianthe Baill. e Capuronianthus J.-F. Leroy devem ser inseridos em Melioideae e Swietenioideae, respectivamente.

Filogeneticamente, Meliaceae é monofilética (Gadek et al. 1996; Muellner et al. 2003) e o grupoirmão dessa família é Simaroubaceae (Muellner et al. 2007). Contudo, as principais análises filogenéticas que trataram dessas questões foram realizadas com baixo número de terminais e em especial, uma baixa amostragem das espécies da região neotropical.
O estado do Espírito Santo é constituído por formações florestais peculiares ao bioma da Mata Atlântica e recentemente muitas espécies novas foram descobertas nessas formações (Filho et al. 2000). Além disso, Meliaceae também está entre as famílias que mais contribuem para a diversidade florística na região neotropical (Gentry 1988) e do ponto de vista econômico, algumas espécies produzem madeira de boa qualidade, como Cedrela fissilis (Souza \& Lorenzi 2010), o que leva a ameaças de extinção graças à pressão de extrativismo.

O presente trabalho trata do estudo das espécies de Meliaceae no estado do Espírito Santo. São apresentados descrições morfológicas, chaves de identificação, ilustrações e comentários taxonômicos.

\section{Material e Métodos}

$\mathrm{O}$ estado do Espírito Santo ocupa uma área de 46.098.571 $\mathrm{km}^{2}$ no Sudeste do Brasil, (IPEMA 2005; Bergamaschi \& França 2011). Sua extensão projeta-se de $17^{\circ} 53^{\prime} 29^{\prime \prime}$ a $21^{\circ} 18^{\prime} 03^{\prime}$ "S de latitude, e de $39^{\circ} 41^{\prime} 18^{\prime \prime}$ a $41^{\circ} 52^{\prime} 45^{\prime \prime} \mathrm{O}$ de longitude, fazendo divisa com os estados da Bahia, Minas Gerais e Rio de Janeiro, além de ser banhado pelo Oceano Atlântico ao leste (Bergamaschi \& França 2011). A vegetação do estado era constituída originalmente por quase $90 \%$ de Mata Atlântica e o restante ocupado por ecossistemas associados (Fundação SOS Mata Atlântica 1993). De acordo com Simonelli \& Fraga (2007), no estado verifica-se cinco formações vegetais: as pioneiras, que são os manguezais e as restingas, a floresta de tabuleiro, a floresta ombrófila densa (submontana, montana e altomontana), a floresta estacional semidecidual (terras baixas, submontana e montana) e os refúgios ecológicos, que correspondem aos campos de altitude. Garbin et al. (2017), apresentam uma discussão sobre o histórico e classificação da vegetação, descrevendo também os principais tipos encontrados no estado.

Para a realização desse trabalho, foram consultados os principais herbários do país com coleções expressivas para o Espírito Santo: CVRD, ESA, HB, INPA, MBM, MBML, R, RB, SP, SPF, UEC e VIES (Thiers, continuamente atualizado). Além disso, foram consultadas imagens de exsicatas em herbários estrangeiros com coleções importantes para o sudeste do Brasil: MO, NY, P e US. Também foram realizadas sete viagens de coleta distribuídas de modo que as plantas fossem visitadas em todas as estações do ano. As análises foram desenvolvidas nas dependências do Laboratório de Sistemática 
Vegetal do Departamento de Ciências Biológicas da Escola Superior de Agricultura "Luiz de Queiroz" (Universidade de São Paulo). A análise morfológica foi realizada através do estudo dos materiais herborizados, incluindo aspectos relevantes do ponto de vista taxonômico, tanto vegetativos como reprodutivos (flores e frutos). As obras de Payne (1978), Hickey (1973), Radford (1974), Harris \& Harris (1995) e Font Quer (1953) foram utilizadas para padronizar a terminologia. Para o exame métrico foram tomadas as medidas máximas e mínimas dos caracteres quantitativos das estruturas analisadas.

A descrição da família Meliaceae foi baseada em Pennington 2016; Pennington \& Clarkson 2013; Pennington \& Müellner 2010; Mabberley et al. 1995; Pennington 1981; Pennington \& Styles 1975; Harms 1940 e De Candolle 1878b.

\section{Resultados e Discussão}

Tratamento taxonômico

Meliaceae Juss., Gen. Pl. 263. 1789

Árvores, arvoretas ou raramente arbustos, gemas protegidas ou não por catafilos, tricomas geralmente simples, papilosos, ocasionalmente estrelados ou menos frequentemente dibraquiados, malpiguiáceos ou escamiformes. Folhas compostas pinadas, com ou sem um folíolo terminal, ocasionalmente bipinadas, trifolioladas, digitadas ou unifolioladas, muitas vezes com uma gema terminal mostrando crescimento intermitente, estípulas ausentes. Folíolos geralmente inteiros, raramente lobados, serreados, crenados ou espinhosos, com ou sem pontuações ou linhas translúcidas.
Inflorescências axilares, menos frequentemente ramifloras, caulifloras ou terminais, determinadas ou indeterminadas, simples, compostas, reduzidas com 2 flores ou solitárias. Flores unissexuadas ou bissexuadas (plantas monoicas, dioicas ou polígamas), frequentemente com estaminódios ou pistilódios bem desenvolvidos. Cálice dialissépalo ou gamossépalo, prefloração aberta, valvar, imbricada ou quincuncial. Corola dialipétala ou pétalas ligeiramente unidas na base, 3-7, prefloração imbricada, quincuncial, convoluta, valvar ou raramente contorta. Estames com filetes unidos formando um tubo, ou parcialmente unidos, raramente livres; anteras (4-)5-10(-14), pilosas ou glabras, inseridas nos filetes, na margem ou no interior do tubo estaminal, parcialmente ou completamente inclusas no tubo, geralmente alternadas com apêndices, raramente opostas. Nectário intra-estaminal, estipitado, colunar, anular, pateliforme, ciatiforme ou ausente, livre ou parcialmente adnado à base do tubo estaminal ou ao ovário. Ovário 2-14 locular, lóculos com 1-multiovulados, óvulos colaterais, sobrepostos ou seriados, placentação axial, estigma capitado, cônico, colunar, lobado ou discoide, pistilódio nas flores masculinas delgado, mas muitas vezes com óvulos não funcionais bem desenvolvidos. Cápsula loculicida ou septífraga, drupa ou baga. Sementes secas, aladas ou não, recobertas totalmente ou parcialmente por sarcotesta ou arilo.

Foram encontradas 25 espécies que pertencem a quatro gêneros de Meliaceae no Espírito Santo. Destas, uma pertence a Cabralea, duas a Cedrela, seis a Guarea e 16 a Trichilia.

\section{Chave de identificação dos gêneros de Meliaceae do Espírito Santo}

1. Lóculos do ovário multiovulados, pétalas adnatas ao androginóforo colunar, cápsula septífraga, sementes aladas. 2. Cedrela

1'. Lóculos do ovário 1-2 ovulados, pétalas livres, androginóforo ausente, cápsula loculicida, sementes não aladas.....

2. Anteras na margem do tubo estaminal ou no ápice dos filetes ...... 2

2'. Anteras inclusas no interior do tubo estaminal ou parcialmente exserta..

3. Folhas com ou sem folíolo terminal reduzido, disco nectarífero ciatiforme........ 1. Cabralea
3'. Folhas com uma gema terminal de crescimento intermitente, disco nectarífero estipitado, quase sempre expandido em colar na base do ovário 3. Guarea

1. Cabralea A. Juss., Mém. Mus. Hist. Nat. 19: 229-230, pl. 5, f. 13. 1830.

Árvores ou arbustos, gemas sem catafilos, tricomas simples. Folhas compostas, paripinadas ou com um folíolo terminal reduzido, raramente imparipinada, gema terminal mostrando crescimento intermitente ausente. Folíolos com pontuações e linhas translúcidas ou não, inteiros. Inflorescências 
geralmente axilares, menos frequentes ramifloras ou caulifloras, determinadas. Flores bissexuadas ou unissexuadas (plantas monoicas ou polígamas). Cálice dialissépalo, prefloração quincuncial. Corola com 5 pétalas livres, prefloração imbricada ou quincuncial, raramente contorta. Estames com filetes completamente ou parcialmente unidos formando um tubo, margem do tubo com (9-)10(12) apêndices curtos e truncados, emarginados ou bilobados. Anteras (9-)10(-12), glabras, inseridas no interior do tubo e alternas aos apêndices deste. Nectário ciatiforme. Ovário (4-)5 locular, lóculos com 2 óvulos, geralmente sobrepostos, estigma discoide. Cápsulas loculicidas, 4-5 valvas, lisas, sépalas não persistentes no fruto, lóculos 1-2 sementes. Sementes não aladas e totalmente ou parcialmente recobertas por um arilo suculento.

Cabralea ocorre exclusivamente na região neotropical e apresenta uma grande variação no porte, desde grandes árvores nas florestas tropicais até pequenos arbustos nos cerrados e regiões montanhosas. No Espírito Santo, Cabralea canjerana se apresentou como uma das principais espécies de Meliaceae nas florestas perenifólias.

1.1. Cabralea canjerana (Vell.) Mart., Syst. Mat. Med. Veg. Bras. 38. $1843 . \quad$ Fig. 1a-f

Árvores ou arbustos, 2-22 m de altura, gemas terminais completamente recobertas por tricomas simples e adpressos, ramos jovens pubescentes, algumas vezes velutinos, amadurecendo glabros. Folhas paripinadas, com ou sem um pequeno prolongamento da raque entre os folíolos terminais, raramente imparipinada, pecíolo 2-20 cm compr., semicilíndrico a canaliculado, esparsamente pubérulo, estrigoso ou glabro, raramente velutino, raque $14,5-46 \mathrm{~cm}$ compr., cilíndrica a levemente achatada, as vezes costada, esparsamente pubérula. Folíolos 7-22, alternos a opostos, peciólulos 2-9 mm compr., lâmina 2,4-19 × 1-5 cm, elíptica, oblonga, lanceolada ou falcada, ápice acuminado, algumas vezes agudo e emarginado, base atenuada, geralmente assimétrica, as vezes decorrente, face abaxial geralmente subglabra, raramente velutina algumas vezes concentrados sobre as aberturas das domácias, face adaxial glabra ou glabrato, frequentemente recoberta por pequenas cavidades a semelhança de poros, algumas vezes apenas nas margens, geralmente com pequenas papilas vermelhas dispersas sobre a lâmina ou com pequenas cavidades a semelhança de poros, nervação eucamptódroma, fracamente reticulada, nervura principal proeminente em ambas as faces, nervuras secundárias impressas ou levemente salientes na face abaxial e impressa na face adaxial, domácias geralmente presentes, pontuações e linhas translúcidas presentes ou não. Inflorescências axilares, ramifloras ou caulifloras, compostas, com ramos laterais principalmente na região basal e mediana, ápice com flores solitárias, 6,5-30 cm compr., estrigosas. Flores amarelas a alvas, pedicelo 1-2 mm compr., estrigoso. Cálice com sépalas ovais a elípticas, estrigosas a pubescentes, margem ciliada. Corola com prefloração imbricada ou quincuncial, pétalas 5-10 × 2,5-3,5 mm, oblongas, face externa papilosa ou glabrata, face interna densamente papilosa, concentradas no ápice e margem. Tubo estaminal 4-7 mm compr., papiloso, ápice do tubo com 7-10 apêndices bilobados alternados com as anteras. Anteras 0,5-1 mm compr., densamente papilosas. Nectário com face externa glabra e a face interna densamente pubescente. Ovário 4-5-locular, com óvulos geralmente sobrepostos, as vezes levemente colaterais, densamente pubescente, estilete densamente papiloso ou glabrato, estigma glabro. Cápsulas 3-4 × 2-3,5 cm, globosas a curtamente elipsoides, base estipitada, ápice arredondado, glabra a esparsamente pubescente, lisa, 4-5 valvas, não reflexas, frequentemente com um exsudado de cor esbranquiçada. Sementes 1-2 cm compr., elipsoides e parcialmente ou totalmente recobertas por um arilo alaranjado.

Material selecionado: Águia Branca, Águas Claras, Zequinha, 7.IX.2006, fr., L.F.S. Magnago et al. 1378 (MBML). Cariacica, Reserva Biológica de Duas Bocas, floresta na biera da estrada para o município de Alegre, 16.II.2008, fr., R.C. Forzza et al. 5042 (MBML, RB). Castelo, Parque Estadual de Forno Grande, 30.X.2004, fr., L. Kollmann et al. 7213 (ESA, MBML). Colatina, margem do Rio Passos, estrada da Colônia, 24.III.1934, fr., J.G. Kuhlmann 43 (RB). Domingos Martins, margem do rio Jacu, 23.VIII.2000, fr., O.J. Pereira \& E. Espindula 6403 (ESA, VIES). Fundão, GoiapabaAçu, 25.VII.2000, fr., V. Demuner et al. 1236 (ESA, MBML). Ibitirama, propr. particular (Paulo Kintão), 27.X.2012, fr., T.B. Flores \& O.R. Campos 1616 (ESA). Linhares, Reserva Natural Vale, Estrada do Flamengo, 21.X.1980, fl., D.A. Folli 282 (CVRD, ESA); Reserva Natural Vale, Estrada Orelha de Onça, 27.IV.1992, fr., D.A. Folli 1613 (CVRD, ESA); Reserva Natural Vale, próximo ao pomar de frutas tropicais, perto da represa, 25.I.1991. fl., D.A. Folli 1464 (CVRD, ESA). Mimoso do Sul, Serra das Torres, 22.VII.2007, fr., $M$. Simonelli et al. 1169 (ESA, MBML). Santa Maria de 

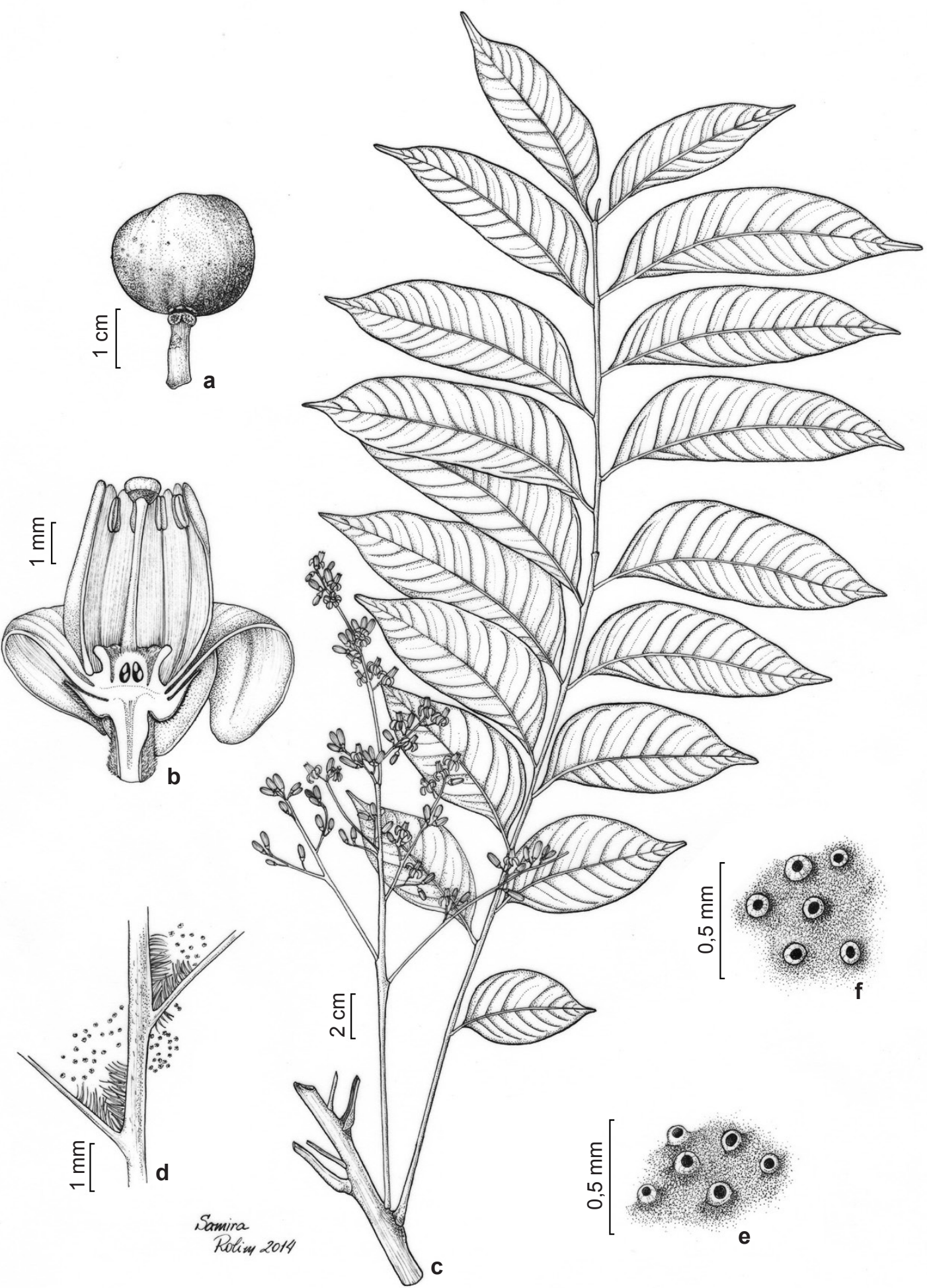

Figura 1 - a-f. Cabralea canjerana - a. fruto; b. flor em corte longitudinal; c. ramo florífero; d. domácias; e. vista lateral das ulcerações na face adaxial da lâmina; f. vista superior das ulcerações na face abaxial da lâmina. (a. Flores 1616; b,c. Folli 1464; d-f. Folli 1613).

Figure 1 - a-f. Cabralea canjerana - a. fruit; b. flower, longitudinal view; c. branch with flowers; d. domatia, detail; e. leaflet, ulcerations on the adaxial surface, lateral view; f. leaflet, ulcerations on the abaxial surface, superior view. (a. Flores 1616; b,c. Folli 1464; d-f. Folli 1613). 
Jetibá, margem do Rio Santa Maria, 30.X.2000, fl., O.J. Pereira \& E. Espindula 6590 (ESA, VIES). Santa Teresa, cabeceira do Rio Bonito, Terreno da Aeronáutica, Radar, 13.VI.2001, fr., L. Kollmann et al. 3944 (MBML); Nova Lombardia, Reserva Biológica Augusto Ruschi, 25.IX.2001, fr., L. Kollmann \& E. Bausen 4721 (ESA, MBML). Vargem Alta, Córrego do Ouro, 26.IV.2009, fr., L. Kollmann 11610 (MBML).

Cabralea canjerana foi coletada com flores nos períodos entre janeiro-abril e junho-setembro, e com frutos entre setembro e dezembro. A distinção dessa espécie é realizada com base na forma do nectário floral (ciatiforme). Contudo, as folhas geralmente paripinadas, com um prolongamento da raque entre os folíolos terminais, a face abaxial dos folíolos geralmente com papilas vermelhas dispersas e a face adaxial geralmente recoberta por pequenas cavidades a semelhança de poros auxiliam no reconhecimento da espécie. Com relação as subespécies apresentadas por Pennington (1981) - C. canjerana subsp. canjerana e C. canjerana subsp. polytricha (A. Juss.) T.D. Penn. - no Espírito Santo foram encontrados dois espécimes ( $V$. Demuner et al. 1236 e L. Kollmann et al. 4721) que apresentam folíolos com formatos e dimensões compatíveis com as de C. canjerana subsp. polytricha (A. Juss.) T.D. Penn., mas não apresentam indumento velutino na face abaxial dos folíolos e o indumento das partes jovens é caduco. Esses são indicativos de que esses espécimes são intermediários entre as duas subespécies apresentadas por Pennington (1981).
2. Cedrela P. Browne, Civ. Nat. Hist. Jamaica 158, pl. 10, f. 1. 1756.

Árvores, gemas com catafilos, tricomas simples. Folhas compostas, paripinadas, gemas terminais mostrando crescimento intermitente ausente. Folíolos com ou sem pontuações e linhas translúcidas, inteiros. Inflorescências frequentemente terminais, menos frequente ramifloras, determinadas, com ramificações de primeira e segunda ordem na região basal e mediana. Flores unissexuais (plantas monoicas). Cálice gamopétalo, com 5 lobos regulares e levemente imbricados, ou largos e irregulares denteado, ou lobado com um dos lados fendido até próximo da base. Corola com 5 pétalas, imbricadas, dialipétalas ou gamopétalas, unidas ao androginóforo colunar por uma membrana mediana na região do nectário. Estames 5, livres entre si, mas com a parte basal dos filetes unidos a base do androginóforo colunar. Anteras 5, inseridas no ápice dos filetes. Androginóforo com a função de nectário rosado ou avermelhado, elavando o ovário. Ovário 5-locular, lóculos 8-14 óvulos. Cápsulas septífragas, eretas ou pêndulas, 5 valvas, lóculos com muitas sementes. Sementes secas e aladas, lateralmente comprimidas.

A maioria das espécies de Cedrela ocorrem exclusivamente na região neotropical e geralmente são árvores grandes com folhas decíduas. No Espírito Santo, foram encontradas as espécies Cedrela odorata L. e Cedrela fissilis Vell (Fig. 2a-j).

\section{Chave de identificação das espécies de Cedrela do Espírito Santo}

1. Lâminas com a face abaxial densamente pubescente, as vezes com tricomas concentrados apenas nas nervuras, frutos 5,5-9 cm compr. 2.1. Cedrela fissilis

1'. Lâminas com a face abaxial glabra ou glabrata, frutos $2-5 \mathrm{~cm}$ compr. 2.2. Cedrela odorata

\subsection{Cedrela fissilis Vell., Fl. Flumin. 75. 1829.}

Fig. $2 \mathrm{a}-\mathrm{f}$

Árvores 8-30 m de altura, gemas densamente pubescentes, ramos jovens pubescentes, amadurecendo glabros. Folhas geralmente com um pequeno prolongamento da raque entre os folíolos terminais, $27-60 \mathrm{~cm}$ compr., pecíolo 4,5-8,5 cm compr., semicilíndrico, pubescente com tricomas concentrados na face plana, raque semicilíndrica, pubescente. Folíolos 18-24, alternos a opostos, peciólulos 0,5-2 $\mathrm{mm}$ compr., lâmina 5-13 × 2-4,5 cm, oblonga a lanceolada, ápice acuminado, base atenuada, geralmente assimétrica, algumas vezes decorrente, face abaxial densamente pubescente, algumas vezes com tricomas concentrados apenas nas nervuras, face adaxial glabra ou glabrata sobre a nervura principal, nervuras proeminentes na face abaxial e impressas ou levemente proeminentes na face adaxial, com domácias, pontuações e linhas translúcidas esparsas ou ausentes. Inflorescências terminais, determinadas, compostas, com ramificações de primeira e segunda ordem, principalmente na base e região mediana, sendo que, o ápice das ramificações 

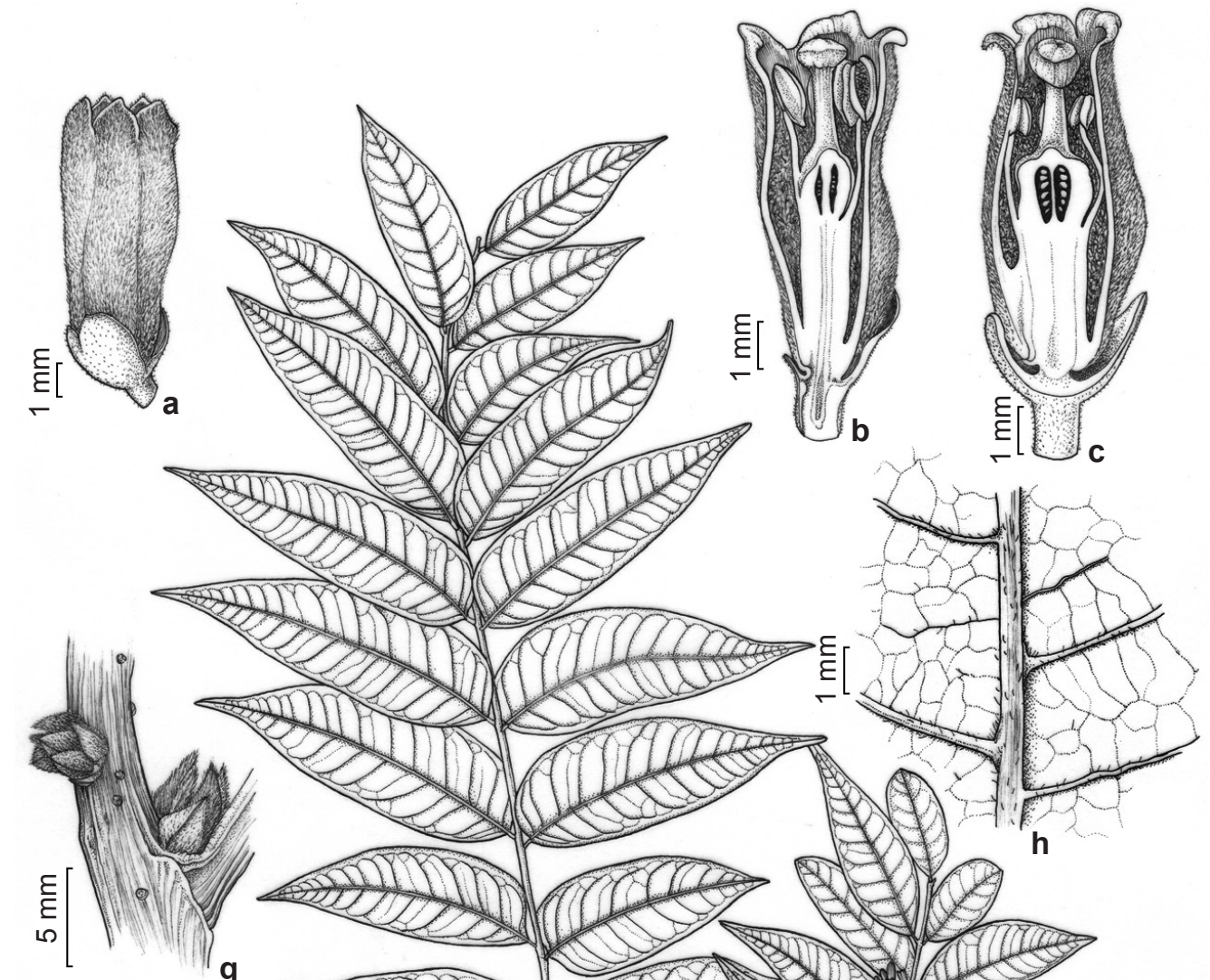

g
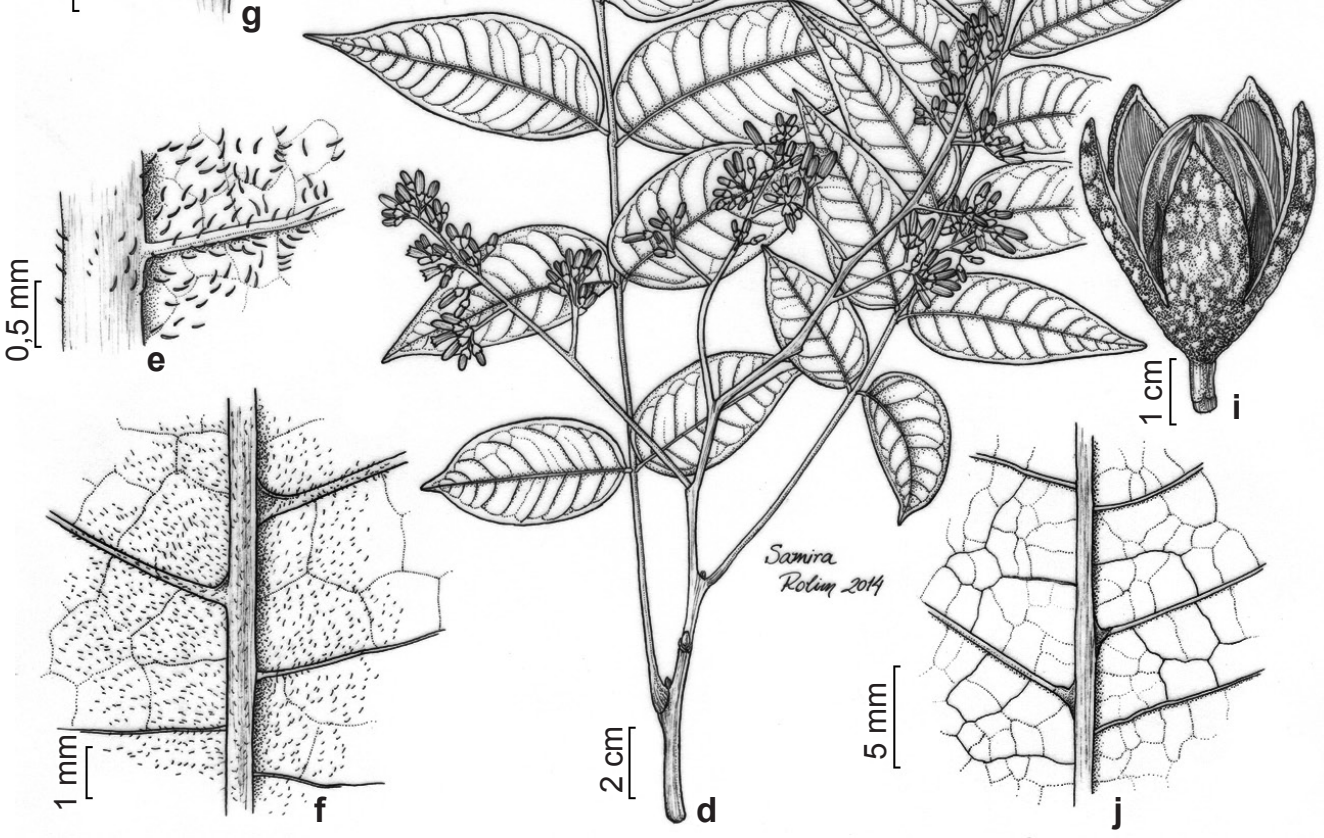

Figura 2 - a-f. Cedrela fissilis - a. vista externa da flor; b. flor masculina em corte longitudinal; c. flor feminina em corte longitudinal; d. ramo florífero; e. detalhe do indumento da face abaxial da lâmina; f. indumento e domácias na face abaxial da lâmina. g-j. Cedrela odorata - g. detalhe das gemas recobertas por catafilos; $h$. indumento na face abaxial da lâmina em um folíolo jovem; i. fruto; j. face abaxial da lâmina glabra em um folíolo maduro. (a-f. Flores 946; g-i. Pereira 6622; j. Pereira 6429). Figure 2 - a-f. Cedrela fissilis - a. flower, external view; b. male flower, longitudinal view; c. female flower, longitudinal view; d. branch with fruits; e. leaflet, hairs in the abaxial surface; f. indumentum and domatia. g-j. Cedrela odorata - g. leaf, detail of the axillary bud covered by cataphylls; h. immature leaflet, hairs in the abaxial surface; i. fruit; j. mature leaflet, abaxial surface. (a-f. Flores 946; g-i. Pereira 6622; j. Pereira 6429). 
é composto por dicásios e monocásios, 10-35 cm compr., pubescentes. Flores amarelas a alvas, pedicelo 0,5-1 $\mathrm{mm}$ compr., pubescente. Cálice irregularmente lobado, sendo que um dos lados apresenta uma profunda fissura até a base do cálice, face externa densamente pubescente, margem ciliada. Corola gamopétala com apenas o ápice livre ou dialipétala, pétalas $8-10 \times 1-1,5 \mathrm{~mm}$, oblongas, face externa pubescente, face interna com longos tricomas irregularmente orientados, muitas vezes entrelaçados com os das pétalas ao lado, margem papilosa. Estames com parte livre com 1,5-3 mm compr., glabros. Anteras $0,5-1 \mathrm{~mm}$ compr., glabras. Androginóforo 4-5 mm compr., glabro. Ovário com óvulos dispostos em duas séries em cada lóculo, glabro, estilete glabro, estigma discoide, papiloso. Cápsulas pêndulas, obovoides, base estipitada, ápice agudo, 5,5-9 × 2-2,5 cm, glabras, lisas, valvas reflexas ou não, sépalas não persistentes nos frutos. Sementes elipsoides e aladas em uma das pontas, 3-4 cm compr., sem arilo.

Material selecionado: Águia Branca, Rochedo, Trilha do Córrego, propr. Ailton Corteleti, 29.XI.2006, fl. e fr., L.F.S. Magnago et al. 1652 (ESA, MBML). Alegre, São João do Norte, próximo à caixa de força, $\mathrm{PCH}$ Santa Fé, 15.X.2008, fl., D.R. Couto \& V. Manhães 980 (ESA, MBML). Baixo Guandú, estrada entre Baixo Guandú e Itaguaçu, 18.X.2001, fl., A.A. Luz 30 (CVRD, ESA). Colatina, São Salvador (Torre 24/3 - LT $230 \mathrm{~km}$, Mascarenhas x Verona), 7.XI.2008, fr., A.M. Assis 1853 (ESA, MBML). Ibitirama, estrada entre os vilarejos de Santa Marta e Pedra Roxa, em frente ao sítio Caparaó, 28.X.2012, fl. e fr., T.B. Flores \& O.R. Campos 1656 (ESA). Laranja da Terra, Lagoinha, 27.X.1969, fl., E.P. Heringer 11896 (HB). Linhares, estrada sentido distrito de Juncado, 29.X.2010, fr., T.B. Flores \& G. Siqueira 963 (ESA); Reserva Natural Vale, aceiro Bragato, 26.X.2010, fl., T.B. Flores \& G. Siqueira 946 (ESA). Marilândia, Liberdade, propr. Deoclécio Lorenccini, 12.VI.2007, fr., V. Demuner 4196 (ESA, MBML). Santa Leopoldina, Suíça, 12.IV.2008, fr., M. Simonelli et al. 1468 (ESA, MBML). Santa Teresa, São João de Petrópolis, Cachoeira do Struts, 3.VIII.2000, fl. e fr., V. Demuner et al. 1338 (ESA, MBML). São Roque do Canaã, Pedra do Pionte (São Bento), propr. Pionte, 28.II.2004, fr., A.P. Fontana et al. 786 (ESA, MBML).

Cedrela fissilis foi coletada com flores entre os meses de julho e novembro e com frutos em quase todos os meses do ano, provavelmente devido ao longo tempo de manutenção da cápsula no ramo. A distinção de $C$. fissilis da outra espécie do gênero é realizada com base no indumento da face abaxial dos folíolos e no tamanho fruto (C. odorata - face abaxial dos folíolos glabros ou glabratos, e frutos 2-5 cm comprimento).
2.2. Cedrela odorata L., Syst. Nat. (ed. 10), 2:940. 1759.

Fig. $2 \mathrm{~g}-\mathrm{j}$

Árvores, $15-27 \mathrm{~m}$ de altura, gemas pubescentes, ramos jovens, geralmente pubescentes, amadurecendo glabros. Folhas geralmente com um pequeno prolongamento da raque entre os folíolos terminais, 20-42 cm compr., pecíolo $2,5-9 \mathrm{~cm}$ compr., semicilíndrico, esparsamente pubérulo, com tricomas concentrados na face plana, raque semicilíndrica, esparsamente pubérula. Folíolos 10-28, alternos a opostos, peciólulo 1-4 mm compr., lâmina 8-25 × 3-7 cm, oblonga, lanceolada ou falcada, ápice acuminado, base atenuada, arredondada a truncada, geralmente assimétrica, face abaxial glabra ou glabrata, face adaxial glabra ou esparsamente pubérula, com tricomas concentrados na nervura principal, nervuras proeminentes na face abaxial e proeminentes ou impressas na face adaxial, com domácias, pontuações e linhas translúcidas ausentes ou esparsas. Inflorescências terminais, determinadas, compostas, com ramificações de primeira e segunda ordem, principalmente na base e região mediana, sendo que o ápice das ramificações é composto por dicásios e monocásios, 9-23 cm compr., pubescentes. Flores amarelas a alvas, pedicelo 0,5-1 $\mathrm{mm}$ compr., pubescente. Cálice irregularmente lobado, sendo que um dos lados apresenta uma profunda fissura até a base do cálice, face externa pubescente, margem ciliada. Corola gamopétala com ápice livre ou dialipétala, pétalas $7-10 \times 1-1,5 \mathrm{~mm}$, oblongas, face externa densamente pubescente, face interna com longos tricomas irregularmente orientados, margem papilosa. Estames com partes livres com 1,5-3 $\mathrm{mm}$, compr., glabros. Anteras 0,5-1 mm compr., glabras. Androginóforo 4-5 mm compr., glabro. Ovário com óvulos dispostos em duas séries em cada lóculo, glabro, estilete glabro, estigma discoide, papiloso. Cápsulas pêndulas, obovoides a elipsoides, base estipitada, ápice agudo, 2-5 × 2-3 $\mathrm{cm}$, glabras, lisas, valvas reflexas ou não, sépalas não persistentes nos frutos. Sementes elipsoides, aladas em uma das pontas, 2-3 cm compr., sem arilo.

Material selecionado: Atilio Vivacqua, Serra de Torres, 21.IV.2007, fr., M. Simonelli et al. 1168 (ESA, MBML). Domingos Martins, margens do Rio Jacu, 24.VIII.2000, fr. O.J. Pereira \& E. Espindula 6429 (ESA, VIES). Dores do Rio Preto, Parque Nacional do Caparaó, arredores do alojamento do ICMBIO, 22.III.2012, fr., J. Kuntz et al. 613 (ESA). Linhares, Reserva Natural Vale, estrada do Flamengo, 18.VII.2006, fr., D.A. Folli 5324 (CVRD, ESA). Nova Venécia, Área de Proteção 
Ambiental Pedra do Elefante, Trilha Principal da Mata do Fuxico, 18.VII.2008, fr., A.M.A. Amorim et al. 7556 (ESA, MBML, RB). Santa Leopoldina, 23.XI.2000, fr., O.J. Pereira \& E. Espindula 6622 (ESA, VIES). Santa Teresa, Nova Lombardia, Reserva Biológica Augusto Ruschi, Estrada Tracomal, 24.IV.2002, fr., R.R. Vervloet \& E. Bausen 175 (ESA, MBML).

Apenas dois espécimes foram coletados com flores em janeiro e fevereiro, e com frutos em quase todos os meses do ano. A distinção de Cedrela odorata é realizada com base no indumento da face abaxial da lâmina e no tamanho dos frutos $(C$. fissilis com indumento densamente pubescente ou as vezes com tricomas concentrados nas nervuras e frutos 5,5-9 × 2-2,5 cm).

3. Guarea F. Allam. ex L., Mant. P1. 2: 150. 1771. Árvores ou arvoretas, gemas geralmente sem catafilos, tricomas simples. Folhas compostas com uma gema terminal mostrando crescimento intermitente, raramente ausente, raramente unifolioladas. Folíolos com ou sem pontuações e linhas translúcidas, inteiros. Inflorescências axilares, ramifloras ou caulifloras, determinadas ou indeterminadas, com ramos laterais de primeira e segunda ordem. Flores unissexuadas (plantas dioicas). Cálice gamossépalo, completamente unido ou até 3-7 lobado, prefloração aberta. Corola dialipétala, (3-)4-6(-7) pétalas, prefloração geralmente valvar, raramente levemente imbricada. Estames com filetes completamente unidos formando um tubo, margem do tubo inteira, crenada ou com pequenos e truncados lobos. Anteras (7-)8-12(-14), glabras ou papilosas, inseridas completamente no interior do tubo ou parcialmente exsertas, alternas aos lobos. Nectário estipitado, geralmente expandido em colar na base do ovário, raramente ausente. Ovário 2-10(-14) locular, lóculos com 1-2 sobrepostos óvulos, estigma discoide. Cápsulas loculicidas, 2-10(-14) valvas, lóculos com 1-2 sementes. Sementes não aladas, envoltas por uma sarcotesta pouco suculenta em geral colorida.

As espécies de Guarea são pequenas arvoretas do sub-bosque até grandes árvores do dossel da floresta e ocorrem exclusivamente na região neotropical. No estado do Espírito Santo foram encontradas seis espécies desse gênero (Fig. 3a-i).

\section{Chave de identificação das espécies de Guarea do Espírito Santo}

1. Ovário e fruto glabros

3.4. Guarea kunthiana

1'. Ovário e fruto pubescentes ou velutinos .

2. Ovário com 2 óvulos sobrepostos por lóculo......................................3.5. Guarea macrophylla

2'. Ovário com 1 óvulo por lóculo

3. Frutos lisos, densamente lenticelados .................................................3.3. Guarea guidonia

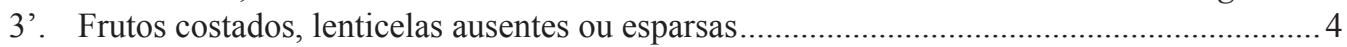

4. Face abaxial do folíolo com nervuras densamente velutinas .........3.6. Guarea pendula

4'. Face abaxial do folíolo com tricomas esparsos sobre as nervuras .................................5

5. Inflorescências axilares

3.2. Guarea gracilis

5'. Inflorescências caulifloras 3.1. Guarea blanchetii

3.1. Guarea blanchetii C. DC., in Mart., Fl. bras. 11(1): 187.1878.

Árvores, 3-6 $\mathrm{m}$ de altura, gemas pubescentes, ramos jovens pubescentes, amadurecendo glabros. Folhas pinadas, com uma gema de crescimento intermitente no ápice da folha, 30-72 cm compr., pecíolo 7,5-22,5 cm compr., semicilíndrico a canaliculado, pubescente na parte plana, pubérulo nas demais partes, raque semicilíndrica a quadrangular, pubérula. Folíolos 8-20, opostos, peciólulo 8-15 mm compr., lâmina 9,5-32 × 7-10 $\mathrm{cm}$, oblonga a lanceolada, ápice acuminado, base aguda a atenuada, face abaxial glabrata nas nervuras e pubérula nas demais partes, papilas vermelhas presentes e dispersa sobre a lâmina, face adaxial glabra ou glabrata, além de pequenas cavidades a semelhança de poros, nervuras proeminentes na abaxial e sulcadas na face adaxial, sem domácias e pontuações translúcidas. Inflorescências caulifloras, compostas, indeterminadas, com pequenos ramos de primeira ordem na região basal e mediana, 5-7,5 $\mathrm{cm}$ compr., pubescentes. Flores amarelas, pedicelo 1-2 mm compr., densamente pubescente. Cálice subemisférico, fortemente lobado com ápices agudos, pubescentes. Corola valvar, pétalas 4, 6-8 $\times 1,5-2 \mathrm{~mm}$, oblongas, face externa densamente 
papilosa, intercalada com muitos tricomas simples e adpressos, face interna densamente papilosa. Tubo estaminal 5-7 mm compr., papiloso, margem ondulada ou com pequenos lobos. Anteras 8, papilosas. Nectário estipitado, elevando o ovário, glabro. Ovário 4-locular, com 1 óvulo por lóculo, densamente pubescente, estilete pubescente, estigma papiloso. Cápsulas depresso-globosas, ápice truncado, base estipitada, 16-24×20-25 mm, densamente papilosa, intercalada com indumento pubescente, lenticelas ausentes, costadas, 4 valvas, não reflexas, sépalas não persistentes nos frutos. Sementes elipsoides, $10-13 \mathrm{~mm}$ compr.

Material selecionado: Linhares, Reserva Natural Vale, ao lado do viveiro, 19.VII.1994, fl., D.A. Folli 2359 (CVRD, ESA). Santa Leopoldina, Bragança, hospedaria Pau a Pique, propr. Assunta Salvador, 30.III.2006, fr., V. Demuner et al. 2176 (ESA, MBML). Santa Teresa, Lombardia, propr. João Furlane, 4.V.2009, fr., A.P. Fontana et al. 5981 (MBML).

Foram encontrados espécimes com flores nos meses de janeiro, julho e outubro e frutos em março e abril. A distinção dessa espécie é realizada com base nas folhas com face abaxial esparsamente pubescente nas nervuras e pubérula nas demais partes, inflorescências caulifloras e frutos costados.

3.2. Guarea gracilis T.D. Penn., Edinburgh J. Bot. 70(2): 272. 2013.

Árvore ou arvoretas, $0,5-7 \mathrm{~m}$ de altura, gemas densamente velutinas, ramos jovens pubescentes, amadurecendo glabros. Folhas pinadas, com um gema terminal apresentando crescimento intermitente, $30-55 \mathrm{~cm}$ compr., pecíolo $2,5-6,5 \mathrm{~cm}$ compr., canaliculado, pubescente, raque cilíndrica a quadrangular, esparsamente pubescente. Folíolos 10-20, geralmente opostos, peciólulo 3-6 mm compr., lâmina 5-15 × 2,5-4,5 cm, lanceolada, oblonga, elíptica, ápice acuminado, base atenuada, algumas vezes decorrente, face abaxial com papilas vermelhas dispersas sobre a lâmina e glabrata sobre as nervuras, face adaxial glabra, nervura principal proeminente na abaxial e sulcada na face adaxial, demais nervuras proeminentes na face abaxial e impressas na face adaxial, sem domácias e com pontuações translúcidas. Inflorescências axilares, compostas, com ramos laterais de primeira ordem, na região basal e mediana, ápice com flores solitárias, 2-22 cm compr., densamente pubescente. Flores creme a alvas, pedicelo $0,5-1 \mathrm{~mm}$ compr., densamente pubescente. Cálice com sépalas unidas na base, triangulares, esparsamente a denso estrigoso. Corola valvar, pétalas 4, 5-8 × 1-2 mm, oblongas a lanceoladas, face externa densamente estrigosa, face interna densamente papilosa. Tubo estaminal 5-7 mm compr., papiloso, margem curtamente lobada. Anteras 8-10, 0,5-1 mm compr., inseridas no interior do tubo, papilosas. Nectário estipitado, elevando o ovário. Ovário 4-locular, 1 óvulo por lóculo, densamente pubescente, estilete esparsamente pubescente, estigma discoide, papiloso. Cápsulas globosas a depresso-globosas, ápice truncado, base curtamente estipitada, 13-15 $\times 15-17 \mathrm{~mm}$, densamente papilosa, intercalado com um indumento pubescente, costada, lenticelas ausentes, 4 valvas, não reflexas, sépalas não persistentes nos frutos. Sementes elipsoides a reniformes, $10-12 \mathrm{~mm}$ comprimento.

Material selecionado: Águia Branca, assentamento 16 de Abril, 15.III.2006, fl., V. Demuner et al. 1997 (ESA, MBML). Linhares, Reserva Natural Vale, Estrada do Flamengo $2 \mathrm{~km}$ a $50 \mathrm{~m}$ da bifurcação com a estrada da Bicuda, lado esquerdo, 20.X.2010, fr., T.B. Flores \& G. Siqueira 894 (ESA). Muniz Freire, Rod. BR-262, 6.IV.1984, fr., G. Hatschbach 47687 (INPA, NY, MO, SPF). Santa Maria de Jetibá, Caramuru, Sítio Jetibá, 26.II.2003, fr., H.Q. Boudet Fernandes et al. 3288 (ESA, MBML). Santa Teresa, Mata Fria, 19.V.1999, fr., W.P. Lopes et al. 728 (ESA, MBML).

Os dados sobre floração são escassos, mas possivelmente, floresce no período chuvoso. Foram encontrados espécimes com frutos entre fevereiro e outubro. Dentre os materiais coletados e identificados, foi possível observar dois grupos que precisam de uma investigação mais ampla. Espécimes coletados na região de Linhares são pequenas arvoretas $(0,5-1,5 \mathrm{~m}$ alt.), pouco ramificadas, com inflorescências $2-3 \mathrm{~cm}$ compr. e com poucas flores. Já nos materiais coletados nas regiões ao sul do estado, é possível verificar árvores altas (até $6 \mathrm{~m}$ de alt.) e bem formadas, com inflorescências maiores (6-22 cm compr.), ramificações distintas e muitas flores.

\subsection{Guarea guidonia (L.) Sleumer, Taxon 5(8):} 194. 1956.

Árvores, $12-15 \mathrm{~m}$ de altura, gemas densamente velutinas, ramos jovens pubescentes, amadurecendo glabros. Folhas pinadas, com uma gema terminal apresentando crescimento intermitente, 15-46 cm compr., pecíolo 6-12 cm compr., canaliculado, pubérulo, raque canaliculada, pubérula. Folíolos 12-20, opostos a subopostos, peciólulo 4-6 mm compr., lâmina 8-25 × 3-6 $\mathrm{cm}$, oblonga, lanceolada, elíptica, ápice agudo a acuminado, base atenuada, algumas vezes decorrente, face abaxial glabra ou glabrata, ou com nervuras esparsamente pubescentes, face adaxial 
glabra, nervura principal proeminente na abaxial, sulcada na face adaxial, secundárias impressas proeminentes na abaxial e na adaxial, sem domácias e pontuações translúcidas. Inflorescências axilares, compostas, ramos laterais de primeira e segunda ordem, na região basal e mediana, ápice com flores solitárias, 20-30 cm compr., pubescente. Flores creme a alvas, pedicelo $0,5-1 \mathrm{~mm}$ compr., densamente pubescente. Cálice subemisférico cilíndrico, irregularmente lobado, pubescente. Corola valvar, pétalas $4-5,5-9 \times 1-2 \mathrm{~mm}$, oblongas a lanceoladas, face externa densamente pubescente, face interna densamente papilosa. Tubo estaminal 4-6 mm compr., papiloso, margem ondulada ou curtamente lobada. Anteras 8-10, 0,5-1 mm compr., inseridas no interior do tubo, papilosas. Nectário estipitado e elevando o ovário. Ovário (3-)4(-5)-locular, 1 óvulo por lóculo, densamente pubescente, estilete esparsamente pubescente, estigma papiloso. Cápsulas globosas a obovadas, ápice arredondado a truncado, base aguda a estipitada, $12-22 \times 12-20 \mathrm{~mm}$, pubescente no ápice, glabro ou glabrato nas demais partes, densamente lenticelada, lisa, (3-)4(-5) valvas, não reflexas, sépalas não persistentes nos frutos. Sementes elipsoides, 9-10 mm compr.

Material selecionado: Águia Branca, Águas Claras, Escola Agroecológica, 1.II.2006, fl., L.F.S. Magnago et al. 529 (ESA, MBML). Alegre, ARIE Laerth Paiva Gama, 15.II.2008, fr., A.M. Assis et al. 1403 (ESA, MBML). Aracruz, Portocel, 19.II.1992, fl. e fr., O.J. Pereira et al. 2724 (ESA, VIES). Barra de São Francisco, cabeceira Córrego do Engenho, terreno de Alfredo Bassi, 12.XII.2000, fl. e fr., L. Kollmann et al. 3492 (ESA, MBML). Cachoeira de Itapemirim, Burarama, 23.V.2009, fl., D.R. Couto et al. 1177 (ESA, MBML). Cariacica, Reserva Biológica de Duas Bocas, Trilha da Represa, 21.VII.2008, fr., A.M.A. Amorim et al. 7632 (MBML, RB). Castelo, estrada entre a sede do Parque Estadual de Forno Grande e o povoado de Pedregulho, 30.X.2012, fl., T.B. Flores \& O.R. Campos 1718 (ESA). Colatina, Faz. Paulo Gala, Angelo Franchiani (Torre 31/1 - LT 230 Kv Mascarenhas x Verona), 3.XII.2008, fr., A.M. Assis 1879 (ESA, MBML). Conceição da Barra, área 100 da Aracruz Celulose S.A., 26.VIII.1992, fl., O.J. Pereira et al. 3810 (VIES). Itapemirim, Fazenda Paineiras, 1.IV.2009, fl. e fr., J.M.L. Gomes et al. 3308 (ESA, VIES). Linhares, estrada entre Linhares e Povoação, 23.X.2010, fr., T.B. Flores 921 (ESA). Muqui, Santa Mônica, torre de celular da Claro, 24.IV.2007, fr., A.P. Fontana et al. 3153 (ESA, MBML). Nova Venécia, Área de Proteção Ambiental da Pedra do Elefante, Serra de Baixo, Fazenda Santa Rita, 19.I.2010, fr., A.M. Assis et al. 2293 (MBML). Pancas, Estrada Pancas a Lajina, 23.III.2007, fl., A.A. Luz 383 (CVRD, ESA). Piúma, Km 70 da estrada entre Piúma e Itapemirim
(ES-060), 9.IX.1977, fr., G.J. Shepherd et al. 5896 (UEC). Santa Maria de Jetibá, cabeceira do Rio Santa Maria, 23.XI.2000, fl., O.J. Pereira \& E. Espindula 6652 (ESA, VIES). Santa Teresa, Córrego Frio, 24.XI.2007, fr., M. Simonelli et al. 1311 (ESA, MBML). São Roque do Canaã, distrito de São Jacinto, Militon, propr. Galon, 16.X.2004, fr., A.P. Fontana et al. 932 (ESA, MBML). Vila Velha, 19.VII.2000, fl., O.J. Pereira \& E. Espindula 6276 (VIES).

Guarea guidonia floresce e frutifica em quase todos os meses do ano e muitas vezes foi encontrada com flores e frutos simultaneamente. Geralmente essa espécie está associada a ambientes ribeirinhos, áreas degradadas e borda de matas. Guarea guidonia pode ser reconhecida pelo ovário com lóculos uniovulados e pela cápsula lisa e densamente lenticelada.

3.4. Guarea kunthiana A. Juss., Bull. Sci. Nat. Geol. 23:240. $1830 . \quad$ Fig. 3i

Árvores ou arvoretas, 2-23 m de altura, gemas densamente velutinas, ramos jovens pubescentes, amadurecendo glabros. Folhas pinadas, com uma gema terminal apresentando crescimento intermitente, $15-46 \mathrm{~cm}$ compr., pecíolo 3,5-6,5 cm compr., semicilíndrico, pubérulo ou pubescente, raque canaliculada, esparsamente a denso pubescente. Folíolos 2-10, alternos a opostos, peciólulo 10-20 mm compr., lâmina 12-30 × 4-17 cm, largo elíptica a lanceolada, ápice agudo, base atenuada, face abaxial glabra, esparsamente pubérula ou densamente pubescente, face adaxial glabra ou glabrata, nervura principal proeminentes na face abaxial e impressas na face adaxial, nervuras secundárias proeminentes na face abaxial e impressas na face adaxial, sem domácias e pontuações translúcidas ausentes ou inconspícuas. Inflorescências axilares, compostas, indeterminadas, ramos laterais de primeira ordem na base e região central, 3,5-30 cm compr., esparsamente pubérulas. Flores creme a alvas, pedicelo 2-3 mm compr., densamente pubescente. Cálice subemisférico cilíndrico, irregularmente lobado, pubescente. Corola valvar, pétalas (3-)4,7-8 × 1,5-2,5 mm, oblongas a lanceoladas, face externa densamente pubescente, face interna densamente papilosa. Tubo estaminal 6-10 mm compr., face externa papilosa, com ou sem tricomas esparsos, face interna papilosa, margem ondulada ou com pequenos lobos truncados. Anteras 8-10, 0,5-1 mm compr., inseridas no interior do tubo, papilosas. Nectário estipitado, elevando o ovário. Ovário 4-locular, 2 sobrepostos óvulos por lóculo, glabro, estilete glabro, estigma papiloso. Cápsulas 


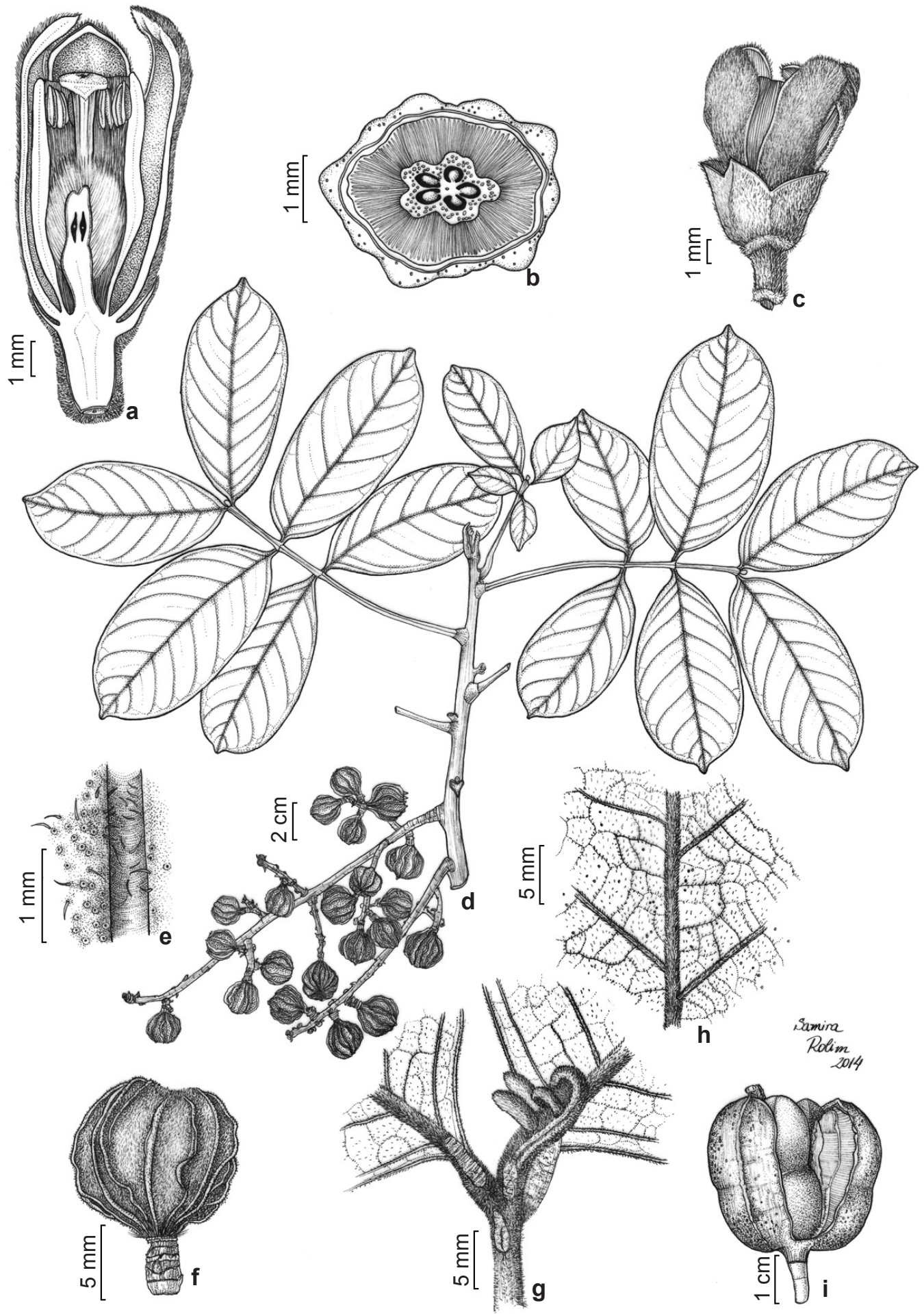

Figura 3 - a-h. Guarea pendula - a. flor em corte longitudinal; b. ovário em corte transversal; c. vista externa da flor; d. ramo frutífero; e. detalhe da nervura principal na face adaxial; f. fruto; g. gema terminal no ápice da folha; h. face abaxial da folha. i. Guarea kunthiana - fruto. (a-c. Folli 218; d,e. Folli 1235; f-h. Folli 4962; i. Magnago 1156). Figure 3 - a-h. Guarea pendula - a. flower, longitudinal view; b. ovary, transversal view; c. flower, external view; d. branch with fruits; e. central vein, detail in the adaxial leaflet surface; f. fruit; g. leaf apex with axillary bud; h. leaf, abaxial surface. i. Guarea kunthiana - fruit. (a-c. Folli 218; d,e. Folli 1235; f-h. Folli 4962; i. Magnago 1156). 
globosas a elipsoides, as vezes quadrangulares, ápice arredondando ou as vezes apiculado, base curta estipitada, 17-35 × 18-30 mm, glabra, densamente lenticelada, lisa ou levemente enrugada, 4 valvas, não reflexas, sépalas não persistentes nos frutos. Sementes elipsoides, 10-15 mm compr.

Material selecionado: Águia Branca, Águas Claras, Escola Agroecológica, 1.II.2006, fl., L.F.S. Magnago et al. 572 (ESA, MBML), Águas Claras, prop. Sr. Voito, 27.VII.2006, fr., L.F.S. Magnago et al. 1156 (ESA, MBML). Alegre, Parque Estadual da Cachoeira da Fumaça, área do Sr. Adalto de Oliveira, 28.XI.2010, fl., M.M. Azevedo et al. 387 (RB). Barra de São Francisco, Córrego das Palmas, terreno de Roberto Strey, 23.XI.2000, fl., L. Kollmann \& E. Bausen 3406 (ESA, MBML). Castelo, estrada entre o Parque Estadual do Forno Grande e o vilarejo de Caxixe Frio, 29.X.2012, fl. e fr., T.B. Flores \& O.R. Campos 1659 (ESA). Nova Venécia, Área de Proteção Ambiental Pedra do Elefante, Serra de Baixo, 19.II.2008, fl., R.C. Forzza et al. 5115 (MBML, RB). Pinheiro, Córrego da Preguiça, 10.XI.1953, fl., A.P. Duarte \& J.C. Gomes 3931 (RB). Santa Leopoldina, Colina Verde, (Morro do Agudo), propr. Israel Elias Ramos, 29.VI.2006, fl. e fr., V. Demuner et al. 2526 (ESA, MBML).

Guarea kunthiana foi encontrada com flores entre os meses de novembro e fevereiro e com frutos nos meses de março, julho e setembro. Essa espécie é distinta pelo ovário e fruto glabros. Os folíolos de grande tamanho em número reduzido e com poucas nervuras secundárias muitas ajudam no reconhecimento da espécie.

3.5. Guarea macrophylla Vahl, Eclog. Amer. 3: 8. 1807.

Árvores ou arvoretas, 3-15 m de altura, gemas densamente velutinas, ramos jovens pubescentes, amadurecendo glabros. Folhas pinadas, com uma gema terminal de crescimento intermitente, 12-30 cm compr., pecíolo 3,5-7 cm compr. semicilíndrico a canaliculado, pubescente, raque canaliculada a quadrangular, pubescente. Folíolos 8-14, geralmente opostos, peciólulo 3-5 mm compr., lâmina $8-17 \times 2,5-5 \mathrm{~cm}$, elíptica a oblonga, ápice acuminado, base aguda a atenuada, algumas vezes decorrente, face abaxial glabrata sobre as nervuras, face adaxial glabra, algumas vezes com pequenos cavidades a semelhança de poros dispersos sobre a lâmina, nervura principal proeminente na face abaxial e sulcada na face adaxial, nervuras secundárias proeminentes na face abaxial, impressas na face adaxial, sem domácias e pontuações translúcidas inconspícuas. Inflorescências axilares, compostas, indeterminadas, com pequenos ramos de primeira ordem na região basal, 4,5-35 cm compr., pubescentes. Flores rosa a alvas, pedicelo 1-2 mm compr., densamente pubescentes. Cálice com sépalas geralmente unidas apenas na base, subemisférico e irregularmente lobado, ou triangular, pubescentes. Corola valvar, pétalas 4 , 7-8 × 1-2 mm, oblongas, face externa densamente pubescente, face interna papilosa. Tubo estaminal 6-8 mm compr., face externa papilosa ou, algumas vezes glabrato, face interna papilosa, margem ondulada ou com pequenos lobos. Anteras 8-10, inseridas no interior do tubo, papilosas. Nectário estipitado, elevando o ovário, glabro. Ovário 4(-5)-locular, 2 óvulos sobrepostos por lóculo, densamente pubescente, estilete pubescente, estigma papiloso. Cápsulas depresso-globosas, largamente elípticas a obovadas, ápice truncado, base curtamente estipitada, 24-35 × 14-21 mm, densamente papilosa, com indumento pubescente, sem lenticelas, lisa ou com ápice verrucoso, ou totalmente verrucosa, 4(-5) valvas, não reflexas, sépalas não persistentes nos frutos. Sementes elipsoides, 10-15 mm compr.

Material selecionado: Águia Branca, Águas Claras, Escola Agroecológica, 6.VI.2006, fr., V. Demuner et al. 2392 (ESA, MBML); Mata do Zequinha, 28.XI.2006, fr., L.F.S. Magnago et al. 1583 (ESA, MBML); propr. Seu Voito, 27.VII.2006, fr., L.F.S. Magnago et al. 1151 (ESA, MBML). Alegre, Pedra da Carneia, 30.VIII.2008, fr., D.R. Couto \& T.R. Couto 853 (ESA, MBML). Cariacica, Reserva Biológica de Duas Bocas, Duas Bocas, Trilha do Pescador, 20.X.2008, fr., C.N. Fraga et al. 2292 (RB). Governador Lindemberg, Pedra de Santa Luzia, propr. Firmino Sottele, 7.XI.2007, fr., V. Demuner et al. 4511 (ESA, MBML). Fundão, Três Barras, 1.VIII.1984, fr., R.M. Piziolo 213 (ESA, MBML). Linhares, Reserva Natural Vale, Trilha do Pequi Vinagreiro, 23.X.2010, fr., T.B. Flores \& G. Siqueira 904 (ESA). Marilândia, Liberdade, propr. Sônia (Reinaldo Bautz), 14.VI.2007, fr., V. Demuner et al. 4278 (ESA, MBML). Nova Venécia, Área de Proteção Ambiental Pedra do Elefante, Serra de Baixo, base da Pedra do Elefante, 9.V.2008, fr., R. Goldenberg et al. 1132 (MBML). Rio Bananal, propr. Santo Carminatt, 19.IX.2009, fr., D.A. Folli 6424 (CVRD, ESA, NY). Santa Leopoldina, Fazenda Caioaba, 19.VII.2007, fr., R.R. Vervloet et al. 2953 (ESA, MBML). Santa Teresa, Nova Lombardia, Reserva Biológica Augusto Ruschi, estrada para Goiapabo-Açu, 11.XII.2001, fl. e fr., L. Kollmann et al. 5182 (ESA, MBML). São Gabriel da Palha, Sítio do Lorenzone, 26.I.2007, fl. e fr., R. Tsuji et al. 1568 (HPL). Vila Velha, Morro do Moreno, 17.XII.2011, fl., W.C. Cardoso 49 (ESA, VIES). 
Guarea macrophylla floresce no período chuvoso e os frutos são encontrados em diversos meses do ano (maio a dezembro). A distinção dessa espécie é realizada com base no ovário densamente pubescente com dois óvulos sobrepostos em cada lóculo. Na obra de Pennington (1981) foram apresentadas cinco subespécies e para realizar a distinção desses táxons, foram utilizados o formato e o indumento dos folíolos, a disposição das nervuras secundárias, o crescimento ou não da gema terminal da folha, o formato e comprimento da inflorescência, o comprimento das pétalas e anteras, o comprimento, forma, textura e indumento dos frutos e finalmente, o número e disposição das sementes em cada valva do fruto. $\mathrm{Na}$ análise dos materiais do Espírito Santo, ficou claro que as informações utilizadas para a separação das subespécies são sobrepostas, muitos espécimes que à primeira vista poderiam ser identificados como uma das subespécies, apresentam uma ou duas características de outra. Por exemplo, L.F.S. Magnago 1151 e 1583, poderiam ser identificados como G. macrophylla subsp. tuberculata mas não apresentam papilas vermelhas na face abaxial que é glabrata, cápsula obovada, fortemente estipitada e pubérula. É possível verificar também, que alguns espécimes em frutos podem ser identificados como G. macrophylla subsp. macrophylla ou G. macrophylla subsp. pachycarpa não sendo possível realizar a distinção entre elas (D.A. Folli 6424, V. Demuner 2392). Além disso, a separação dos materiais com flores, muitas vezes é baseada em uma diferença menor que $1 \mathrm{~mm}$ de comprimento das estruturas (pétalas e anteras) e que mesmo assim é contínua com uma ou outra subespécie. As informações sobre inflorescências são incompletas e desiguais. Considerou-se assim, que a divisão em subespécies para G. macrophylla, conforme apresentado por Pennington (1981), necessitam de maiores estudos.

3.6. Guarea pendula R. da Silva Ramalho, A.L. Pinheiro \& T.D. Penn., Revista Árvore 11:185. 1987.

Fig. 3a-h

Árvores, 3-19 m de altura, gemas densamente velutinas, ramos jovens pubescentes. Folhas pinadas, com uma gema terminal de crescimento intermitente, $15-45 \mathrm{~cm}$ compr., pecíolo $2.5-10,5 \mathrm{~cm}$ compr., semicilíndrico a canaliculado, pubescente a velutino, raque cilíndrica a canaliculada, pubescente a velutina.
Folíolos 6-20, alternos a opostos, peciólulo 2-10 mm compr., lâmina $10-29 \times 3-10 \mathrm{~cm}$, oblonga, elíptica, lanceolada, ápice acuminado, base atenuada, algumas vezes decorrente, face abaxial densamente velutina nas nervuras, pubescente nas demais partes, além de papilas vermelhas dispersas sobre a lâmina, face adaxial com tricomas concentrados na nervura principal e esparsos sobre a lâmina, geralmente, com pequenas cavidades a semelhança de poros, nervura principal proeminente na face abaxial e sulcada na face adaxial, nervuras secundárias proeminentes na face abaxial e sulcadas na face adaxial, sem domácias e pontuações translúcidas. Inflorescências axilares, ramifloras e caulifloras, compostas, indeterminadas, com ramos laterais de primeira e segunda ordem na região basal e mediana 9-35 cm compr., densamente pubescentes a velutinas. Flores creme, pedicelo 1,5-3 mm compr., densamente pubescente a velutino. Cálice subemisférico a cilíndrico, ápice com lobos agudos, pubescente. Corola valvar, pétalas $4,7-8 \times 1-2 \mathrm{~mm}$, oblongas, face externa densamente pubescente a velutina, face interna papilosa. Tubo estaminal $6-8 \mathrm{~mm}$ compr., glabro ou densamente papiloso, intercalado com longos tricomas esparsos, margem ondulada ou com pequenos lobos truncados. Anteras $8,0,5-1 \mathrm{~mm}$ compr., inseridas no interior do tubo, papilosas. Nectário estipitado, elevando o ovário, glabro. Ovário 4(-5)-locular, com 1 óvulo por lóculo, densamente pubescente a velutino, estilete esparso pubescente, estigma glabro. Cápsulas depresso-globosas, ápice truncado, base curtamente estipitada, $18-25 \times 14-25 \mathrm{~mm}$, densamente pubérulas, pubescentes a velutina, com uma grande concentração de tricomas na base, costadas, lenticelas ausentes, 4 valvas, não reflexas, sépalas não persistes nos frutos. Sementes elipsoides, 10-15 mm compr.

Material selecionado: Cariacica, Pau Amarelo, exCondomínio Rural Cantinho do Céu, 12.IV.2009, fl., $L$. Kollmann et al. 11537 (MBML, RB). Ibitirama, propr. particular (Alcindo Luis Mota Filho) a $5 \mathrm{~km}$ da estrada do município de Ibitirama, 26.X.2012, fl. e fr., T.B. Flores \& O.R. Campos 1579 (ESA). Linhares, Reserva Natural Vale, Estrada do Flamengo, 3.IV.1980, fl., D.A. Folli 218 (CVRD, ESA); 25.X.2004, fr., D.A. Folli 4962 (CVRD, ESA); Estrada da Gávea, 20.IX.1991, fr., D.A. Folli 1235 (CVRD, ESA). Santa Maria de Jetibá, Belém, terreno de Paulo Seick, 19.XI.2002, fr., L. Kollmann et al. 5758 (ESA, MBML).

No Espírito Santo foram encontrados espécimes florescendo nos meses de março, abril 
e outubro, e frutificando em setembro e outubro. A distinção dessa espécie pode ser realizada com base no indumento da face abaxial dos folíolos (velutino nas nervuras e densamente pubescente no resto da lâmina), da inflorescência (densamente pubescente a velutino) e do fruto (pubescente a velutino), além de sua textura (costados). No estado, foi possível observar dois grupos de materiais que compõem essa espécie e precisam de uma investigação mais ampla. O primeiro grupo são árvores de grande a médio porte (11-19 $\mathrm{m}$ de alt.), bastante ramificadas, com inflorescências axilares, muito ramificadas, $15-35 \mathrm{~cm}$ compr., não apresentando flores e frutos maduros na mesma inflorescência e ocorre principalmente na região das florestas de tabuleiro. Já o segundo grupo, é composto por pequenas árvores (2-4,5 $\mathrm{m}$ de alt.), pouco ramificadas, com tronco densamente suberoso e fissurado, inflorescências em sua maioria caulifloras, pouco ramificadas, 9-22 cm compr. e apresentam conjuntamente flores e frutos maduros, além de ser encontrada mais ao sul do Estado em topo de morros e matas de encosta. Pennington \& Clarkson (2013) propõem a inclusão de Guarea penningtoniana Pinheiro como sinônimo de $G$. pendula e aparentemente, esses dois grupos que foram encontrados se enquadram nos respectivos táxon, a análise de materiais de outros Estados é necessária para se tomar uma decisão.

4. Trichilia P. Browne, Civ. Nat. Hist. Jamaica 278. 1756.

Árvores ou arbustos, gemas terminais geralmente sem catafilos, tricomas geralmente simples, papilosos ou, menos frequente dibraquiados, estrelados ou escamiformes. Folhas compostas pinadas, com ou sem um folíolo terminal, trifoliodas, unifolioladas ou raramente digitadas, sem gema terminal no ápice. Folíolos com ou sem pontuações e estrias translúcidas, inteiros, face abaxial da lâmina com domácias nas axilas das nervuras secundárias, raramente próximas às margens ou dispersas sobre a lâmina ou ausentes. Inflorescências axilares, ramifloras ou caulifloras, determinadas ou indeterminadas, raramente, reduzidas a poucas flores. Flores usualmente unissexuadas (plantas dioicas). Cálice geralmente gamossépalo, raramente dialissépalo. Corola livres ou parcialmente unidas entre si, prefloração valvar, imbricada ou raramente quincuncial, pétalas (3-)4-5(-6). Estames com filetes completamente ou parcialmente unidos formando um tubo, raramente livres. Anteras (4-)5-10(-11), inseridas entre dois apêndices ou lobos na margem do tubo estaminal ou sobre os filetes livres. Nectário geralmente anelar envolvendo a base do ovário, menos frequente estipitado, pateliforme ou ciatiforme, raramente unido à base do tubo estaminal ou ausente. Ovário 2-3(-4)-locular, lóculos com 1-2 óvulos colaterais, menos frequente sobrepostos, estigma usualmente capitado, menos frequente discoides, cônico ou colunar, com ou sem lobos. Cápsulas loculicidas, 2-3(-4) valvas, lisas a verrucosas, sépalas persistentes ou não nos frutos, lóculos 1-2 sementes. Sementes não aladas, parcialmente ou completamente recobertas com arilo.

$\mathrm{O}$ gênero ocorre principalmente na região neotropical com aproximadamente 100 espécies (Pennington 2016). No Brasil, Stefano et al. (2015) relatam a ocorrência de 46 espécies ( 24 exclusivas). No Espírito Santo foram encontradas 16 espécies e duas delas são tratadas provisoriamente como Trichilia sp. 1 e Trichilia sp. 2, e para essas espécies serão preparados manuscritos específicos para sua descrição (Fig. 4a-r; 5a-k).

\section{Chave de identificação das espécies de Trichilia do Espírito Santo}

1. Folhas unifolioladas, ápice do pecíolo com duas projeções laterais. 4.1. Trichilia blanchetii

1'. Folhas imparipinadas, paripinadas, trifolioladas ou se unifolioladas associadas no mesmo ramo a folhas trifolioladas, ápice do pecíolo sem projeções laterais.

2. Raque da folha estreitamente alada. 4.4. Trichilia emarginata

2'. Raque da folha não alada 3

3. Face abaxial da lâmina com tricomas estrelados ou escamiformes ..... 4.6. Trichilia lepidota

3'. Face abaxial da lâmina glabra ou com tricomas simples ou raramente dibraquiados .......... 4

4. Folíolos basais vestigiais, filiformes ou quando extremamente menores e com formato extremamente distinto dos demais, base fortemente assimétrica, algumas vezes, posicionados como um par de estípulas (pseudoestípula), algumas vezes, precocemente caduco, deixando apenas cicatrizes na base da folha. .5

4'. Folíolos basais similares aos demais. 
5. Folhas com dois ou mais pares de folíolos basais vestigiais, filiformes ou menores e com formato distinto dos demais. 4.16. Trichilia sp. 2

5'. Folhas com apenas um par de folíolos basais vestigiais, filiformes ou menores e com formato distinto dos demais.

6. Inflorescências fasciculadas 4.10. Trichilia pseudostipularis

6'. Inflorescências não fasciculadas

7. Partes jovens, face abaxial dos folíolos e inflorescência com indumento tomentoso, tricomas não adpressos

4.12. Trichilia ramalhoi

7'. Partes jovens, face abaxial da lâmina e inflorescências pubérulas ou pubescentes, formado por tricomas simples e adpressos ou dibraquiados

8. Folíolos basais com lâmina expandida, não vestigiais ou filiformes, inflorescências $1-4 \mathrm{~cm}$ compr., frutos $15-18 \times 5-8 \mathrm{~mm}$ 4.14. Trichilia tetrapetala

8'. Folíolos basais vestigiais ou filiformes, geralmente precocemente caducos, inflorescência 4-13,5 cm compr., frutos $20-35 \times 8-11 \mathrm{~mm}$..... 4.11. Trichilia quadrijuga

9. Corola com prefloração valvar 10

9'. Corola com prefloração imbricada 12

10. Inflorescência fasciculada 4.7. Trichilia magnifoliola

10'. Inflorescência não fasciculada 11

11. Folhas 5-7 folíolos, face adaxial do folíolo glabro; frutos $12-20 \mathrm{~mm}$ compr. 4.13. Trichilia silvatica

11'. Folhas 7-12 folíolos, face adaxial do folíolo com nervura principal pubescente; frutos 20-35 mm compr.

4.11. Trichilia quadrijuga 12. Filetes dos estames parcialmente unidos formando um tubo ............... 13

12'. Filetes dos estames completamente unidos formando um tubo ........... 14

13. Gemas terminais sem catafilos, folhas 3-7 folíolos, inflorescências fasciculadas, 1,5-3,5 cm compr., ápice dos filetes com dois lobos agudos maiores ou com o mesmo tamanho que as anteras, sépalas persistentes nos frutos 4.9. Trichilia pallida

13'. Gemas terminais com catafilos, folhas 7-19 folíolos, inflorescências não fasciculadas, $10-21 \mathrm{~cm}$ compr., ápice dos filetes com dois lobos agudos muito menores que as anteras, sépalas não persistentes nos frutos. 4.5. Trichilia hirta

14. Ovário densamente pubescente 4.15. Trichilia sp. 1

14'. Ovário glabro. 15

15. Domácias nas axilas das nervuras secundárias, próximas as margens ou dispersas sobre a lâmina, fruto não papiloso 4.2. Trichilia casaretti

15'. Domácias ausentes ou apenas nas axilas das nervuras secundárias, fruto papiloso

16. Pontuações e estrias translúcidas muito evidentes, face externa das pétalas e anteras papilosas

16'. Pontuações e estrias translúcidas ausentes ou pouco evidentes, face externa das pétalas papilosas e estrigosas, anteras papilosas e pubescentes

4.1. Trichilia blanchetii C. DC., in Mart., Fl. bras. 11(1):217. 1878.

Árvores, ca. $4 \mathrm{~m}$ de altura, gemas terminais sem catafilos, densamente velutinas, intercalando tricomas simples e dibraquiados, ramos jovens esparsamente pubescentes, amadurecendo glabros. Folhas unifolioladas, 9-12 cm compr., pecíolo 1-2 cm compr., canaliculado, com duas projeções laterais no ápice, esparsamente estrigoso, formado por tricomas simples e dibraquiados. Folíolos 
sésseis ou com peciólulos de até $1 \mathrm{~mm}$ compr., canaliculados, glabros ou glabratos, lâmina 7,5-12 $\times$ 3-5 cm, elíptica a oblonga, ápice acuminado a emarginado, mucronado ou não, base aguda a decorrente, face abaxial glabra ou glabrata, face adaxial glabra, nervura principal proeminente em ambas as faces, nervuras secundárias proeminentes na face abaxial e inclusas ou impressas na face adaxial, sem domácias e pontuações translúcidas. Inflorescências axilares, determinadas, compostas, com ramos de primeira ordem na região basal, ápice com flores solitárias, $1-2,5 \mathrm{~cm}$ compr., esparsamente estrigosas. Flores alvas, pedicelo 1-2 mm compr., esparsamente estrigoso a glabro. Cálice gamossépalo, subemisférico, com lobos agudos, esparsamente estrigoso. Corola valvar, dialipétala, $4-5$ pétalas, $3-4 \times 1-2 \mathrm{~mm}$, triangulares a lanceoladas, face externa papilosa e estrigosa, face interna papilosa. Estames com filetes completamente unidos formando um tubo, 3-4 $\mathrm{mm}$ compr., face externa glabrata, face interna com tricomas longos e irregularmente orientados, principalmente concentrados na parte superior, ápice do tubo com lobos filiformes, alternos com as anteras e ca. a metade do tamanho dessas. Anteras 7-8, 0,5-1,5 mm compr., densamente papilosas. Nectário ausente. Pistilódio 3-locular com 2 "óvulos" colaterais em cada lóculo, densamente pubescente com tricomas adpressos. Flores femininas não vistas. Cápsulas não vistas.

Material examinado: Governador Lindemberg, Morelo, propr. Fernando Nicolli, 13.XI.2006, fl., V. Demuner et al. 3034 (ESA, MBML).

Trichilia blanchetii era conhecida apenas para o estado da Bahia (Pennington 2016) e o espécime V. Demuner et al. 3034 é a primeira referência dessa espécie para o Espírito Santo. Esse material foi coletado com flores em novembro. Trichilia blanchetii é facilmente distinta por apresentar folhas unifolioladas e o ápice do pecíolo com duas projeções laterais.

4.2. Trichilia casaretti C. DC., in Mart., Fl. bras. 11(1):217. 1878.

Árvores ou arbustos, 3-15 m de altura, gemas terminais sem catafilos e densamente velutinas, ramos jovens estrigosos, amadurecendo glabros. Folhas trifolioladas ou imparipinadas, 13-20 cm compr., pecíolo 1,7-4 cm compr., achatado, esparsamente estrigoso, sem projeções laterais, raque achatada, pubérula. Folíolo 3-7, opostos, basais similares aos demais, peciólulo $2-4 \mathrm{~mm}$ compr., canaliculado, geralmente pubescente, raramente glabro, lâmina $3-17 \times 1,5-8,5 \mathrm{~cm}$, elíptica a oboval, ápice acuminado, geralmente com um pequeno mucro, base atenuada, algumas vezes decorrente, face abaxial geralmente glabra, algumas vezes com tricomas simples e esparsos sobre a lâmina ou nervuras, face adaxial glabra, nervura principal proeminente ou impressa em ambas as faces, nervuras secundárias proeminentes ou impressas em ambas as faces, domácias presentes nas axilas das nervuras secundárias, próximas as margens ou dispersas sobre a lâmina, sem pontuações e linhas translúcidas ou de difícil visualização, raramente evidentes a olho nu. Inflorescências axilares, determinadas, compostas, com ramos laterais principalmente na região basal e central, ápice com flores solitárias, 4-10,5 cm compr., glabras. Flores amarelas a alvas, pedicelo 2-3 mm compr., glabro ou glabrato. Cálice gamossépalo, subemisférico e irregularmente lobado com ápices agudos, geralmente glabros ou, algumas vezes com a margem ciliada. Corola imbricada, dialipétala, pétalas 5, 2-4 × 1-1,5 mm, oblongas a lanceoladas, face externa papilosa, face interna densamente papilosa e com tricomas longos e esparsos. Estames com filetes completamente unidos formando um tubo, $2-3,5 \mathrm{~mm}$ compr., face externa glabra ou densamente papilosa, face interna papilosa e com tricomas longos irregularmente orientados, concentrados principalmente na parte superior do tubo, ápice do tubo com 8-10 lobos agudos, alternados com as anteras, do mesmo tamanho ou um pouco menores que essas. Anteras 8-10, 0,5-1,5 mm compr., papilosas. Nectário anelar fundido a base do ovário, raramente ausente. Ovário 3-locular com 2 óvulos colaterais em cada lóculo, glabro, estilete glabro, estigma trilobado, papiloso. Cápsulas elipsoides, estipitadas, ápice truncado a emarginado, mucronado a rostrado, 14 $22 \times 3-12 \mathrm{~mm}$, glabras ou raramente esparsamente a densamente pubérulas, levemente enrugadas, com sulcos bem marcados delimitando as valvas, com 3 valvas, reflexas, sépalas persistentes no fruto. Sementes 1-2 mm compr., elipsoide, recobertas parcialmente por arilo alaranjado.

Material selecionado: Alegre, São João do Norte, $\mathrm{PCH}$ Santa Fé, Barragem de Geração, parcela 9, 28.I.2009, fr., D.R. Couto et al. 1082 (ESA, MBML). Baixo Guandú, estrada Baixo Guandú a Alto Lage, 10.VII.2002, fr., A.A. Luz 65 (CVRD, ESA). Cachoeira de Itapemirim, estrada para Itabira, 25.IV.1972, fr., D. Sucre \& T. Soderstrom 8955 (ESA, RB). Cariacica, Sitio Taquararuçú, 4.VII.2004, fr., F.Z. Saiter 101 (ESA, VIES). Castelo, Caxixe Quente, 18.V.1999, fr., G. Hatschbach et al. 69159 (MBML). Guarapari, Parque Estadual Paulo 
César Vinha, 27.VI.1995, fl. e fr., O. Zambom et al. 6 (ESA, VIES). Itapemirim, Marataízes, 21.V.1999, fr., G. Hatschbach et al. 69244 (ESA, MBML, SPF). Linhares, Reserva Natural Vale, Estrada do Bobbil, 13.V.2009, fr., G.D. Colletta et al. 303 (ESA). Nova Venécia, Área de Proteção Ambiental Pedra do Elefante, Serra de Baixo, Fazenda Neblina, 15.I.2009, fl., A.P. Fontana et al. 5792 (MBML, RB, SPF). Piúma, Ilha do Francês, 1.XI.2002, fl., H.L. Pinheiro et al. 79 (ESA, VIES). Rio Bananal, alto mun. de Rio Bananal, 1.VIII.2007, fr., R.R. Vervloet et al. 3092 (ESA, MBML). Santa Leopoldina, Fazenda Caioba, 19.VII.2007, fr., R.R. Verveloet et al. 2956 (MBML). Santa Teresa, Escola Agrotécnica Federal da Santa Teresa, 12.V.1999, fr., W.P. Lopes et al. 683 (ESA, MBML). Serra, Bacia Rio Jacaraípe, 14.IV.1997, fr., O.J. Pereira 7694 (ESA, VIES). Vila Velha, Interlagos, 1.VI.1995, fr., O.J. Pereira et al. 5454 (ESA, VIES). Vitória, Parque Municipal da Fonte Grande, 13.VII.2004, fr., M.L. Dan 75 (ESA, VIES).

No Espírito Santo, Trichilia casaretti apresenta dois períodos de floração no ano (outubro a janeiro e junho a julho) e foi coletada com frutos em quase todos os meses do ano. Essa espécie é correlacionada morfologicamente com $T$. elegans e a distinção entre elas pode ser realizada com base nas domácias próximas às margens dos folíolos ou dispersas sobre a lâmina e o fruto com indumento não papiloso de T. casaretti.

4.3. Trichilia elegans A. Juss., Fl. bras. Merid. 2(12):79, pl. 98. 1829.

Árvores, 3-10 m de altura, gemas terminais sem catafilos e densamente velutinas, ramos jovens estrigosos ou densamente pubescentes, amadurecendo glabros ou não. Folhas trifolioladas, imparipinadas ou paripinadas, 13-28 cm compr., pecíolo 2,5-6,5 cm compr., cilíndrico a achatado, estrigoso ou densamente pubescente, sem projeções laterais, raque cilíndrica a achatada, estrigosa ou densamente pubescente. Folíolos 3-9, opostos, basais similares aos demais, peciólulo de 2-13 $\mathrm{mm}$, com os do ápice muito maiores que os demais, canaliculados, esparsamente pubérulo a densamente pubescente, lâmina 5-14 × 2,5-5 $\mathrm{cm}$, elíptica a lanceolada, ápice acuminado, geralmente com um pequeno mucro, base atenuada, algumas vezes decorrente, face abaxial com tricomas simples, geralmente concentrados sobre as domácias, menos frequente esparsos sobre a lâmina ou densamente pubescente, face adaxial glabra a pubescente com tricomas concentrados nas nervuras, nervura principal proeminente na face abaxial e impressa ou inclusa na face adaxial, nervuras secundárias proeminentes na face abaxial e impressas ou inclusas na face adaxial, domácias nas axilas das nervuras secundárias, pontuações e linhas translúcidas muito evidentes. Inflorescências axilares, determinadas, compostas, com ramos laterais principalmente na região basal e central, ápice com flores solitárias, 4-26 cm compr., esparsamente pubérulas a densamente pubescentes. Flores amarelas a alvas, pedicelo 2-3 $\mathrm{mm}$ compr., glabros a densamente pubescente. Cálice gamossépalo, subemisférico e irregularmente lobado, com ápices agudos, ou sépalas unidas apenas na base, lanceoladas a triangulares, com apenas as margens ciliadas ou densamente pubescente. Corola imbricada, dialipétala, pétalas 5, 2,5-5 × 1-2 mm, oblongas a lanceoladas, face externa papilosa, face interna densamente papilosa. Estames com filetes completamente unidos formando um tubo, 2-3,5 mm compr., face externa densamente papilosa, face interna papilosa, ápice do tubo com 9-10 lobos, alternos com as anteras e muito menores que essas. Anteras 9-10, 0,5-1,5 mm compr. papilosas, Nectário anelar fundido a base do ovário, raramente ausente. Ovário 3-locular com 2 óvulos colaterais em cada lóculo, glabro, estilete glabro, estigma trilobado ou capitado. Cápsulas elipsoides a trigonais, base truncada a curtamente estipitada, ápice agudo a arredondado, geralmente com um mucro, algumas vezes rostrado, 8-15 × 6-12 mm, densamente papilosas ou esparsamente a densamente pubescente, lisas ou densamente verrucosas, com 3 valvas, reflexas, sépalas persistentes no fruto. Sementes 5-9 mm compr., elipsoides, recobertas parcialmente por arilo vermelho a alaranjado.

Material selecionado: Aracruz, Rodovia CoqueiralRegência, ramal E da estrada a 2 km do trevo de Barra do Riacho, Restinga de Camboios, propr. Aracruz Florestal S.A., 21.II.1994, J.R. Pirani 3061 (SPF, NY). Cachoeira de Itapemirim, EMCAPA, Bananal do Norte, 24.IX.1991, fr., V. de Souza 197 (CVRD, ESA, RB). Cariacica, Reserva Biológica de Duas Bocas, Trilha da Represa, 21.VII.2008, fr., R.C. Forzza et al. 5278 (MBML, RB). Guarapari, Setiba, próximo a Carais, 26.III.1991, fr., L.C. Fabris \& L.D. Thomaz 670 (VIES). Itapemirim, Fazenda do Pinto, 1.IV.2009, fr., Sarnaglia Junior V.B. et al. 22 (ESA, VIES). Linhares, aceiro do Colimã, antigo marco de Ferro, 9.XII.1993, fl., D.A. Folli 2114 (CVRD, ESA). Presidente Kennedy, Praias das Neves, 27.IV.1997, fr., O.J. Pereira et al. 5777 (ESA, VIES). Santa Leopoldina, Colina Verde (Morro do Agudo), propr. Dona Maria, 15.III.2007, fr., V. Demuner et al. 3226 (ESA, MBML). Vitória, Parque Municipal da Fonte Grande, 12.VIII.2004, fr., M.L. Dan 77 (ESA, VIES).

Trichilia elegans foi coletada com flores entre os meses de setembro e janeiro, e com frutos em quase todos os meses do ano. Essa espécie 
é correlacionada morfologicamente a T. pallens e pode ser distinta com base nos folíolos com pontuações e linhas translúcidas muito evidentes, face externa das pétalas e anteras papilosas (contra os folíolos com pontuações e estrias translúcidas pouco evidentes, face externa das pétalas papilosas e estrigosas e anteras papilosas e pubescentes de T. pallens).

4.4. Trichilia emarginata (Turcz.) C. DC., in Mart., Fl. bras. 11(1): 212. 1878.

Árvores ou arbustos, 2,5-13 m de altura, gemas terminais sem catafilos, densamente velutinas, ramos jovens estrigosos, amadurecendo glabros. Folhas imparipinadas ou paripinadas, com um dos folíolos do par apical simulando o terminal, 7-20 cm compr., pecíolo 1,2-2,9 cm compr., semicilíndrico a canaliculado, estrigoso, com tricomas concentrados principalmente na base ou glabros, sem projeções laterais, raque estreitamente alada, algumas vezes extremamente costada na face superior, esparsamente estrigosa a glabra. Folíolos 5-11, basais similares aos demais, alternos a opostos, sésseis, lâmina 2,5-10 × 1-3,5 $\mathrm{cm}$, elíptica, oblonga ou raramente obovada, ápice emarginado, geralmente com um mucro entre os lobos, base atenuada, algumas vezes assimétrica, face abaxial glabrata, face adaxial glabra ou glabrata, com tricomas concentrados sobre as nervuras, nervura principal proeminente em ambas as faces, nervuras secundárias impressas ou levemente salientes em ambas as faces, sem domácias, com pontuações e linhas translúcidas ou não. Inflorescências axilares, determinadas, compostas, com ramos laterais principalmente na região basal e central, ápice com flores solitárias, 3,5-11 cm compr., estrigosas. Flores amarelas a alvas, pedicelo 0,5-1 mm compr., estrigoso. Cálice gamossépalo, subemisférico e irregularmente lobado, face interna glabra, face externa estrigosa. Corola valvar ou levemente imbricada, dialipétala, pétalas $4-5,2-3,5 \times 1-1,5 \mathrm{~mm}$, oblongas, lanceoladas ou triangulares, face externa papilosa e com tricomas adpressos e esparsos, face interna densamente papilosa. Estames com filetes completamente unidos formando um tubo, 1,5-2,5 $\mathrm{mm}$ compr., face externa densamente papilosa e com tricomas longos e irregularmente orientados, concentrados principalmente na parte superior, face interna densamente papilosa e com tricomas longos e irregularmente orientados, ápice do tubo com 8-10 lobos agudos, alternados com as anteras e ca. a metade do tamanho dessas. Anteras
8-10, 0,5-1,5 mm compr., densamente papilosas. Nectário ausente. Ovário 3-locular com 2 óvulos colaterais em cada lóculo, densamente estrigoso, estilete glabro, estigma capitado a trilobado, glabro. Cápsulas oblongas, base truncada, ápice arredondado, mucronado, 15-18 × 7-10 mm, densamente papilosas com tricomas simples e adpressos, principalmente concentrados na base e no ápice do fruto, lisas, com 3 valvas, não reflexas, sépalas não persistentes no fruto. Sementes 10-15 mm compr., elipsoides, completamente recobertas por um arilo alvo ou vermelho.

Material selecionado: Águia Branca, localidade 16 de abril, 17.X.2006, fr., V. Demuner et al. 2904 (ESA, MBML). Barra de São Francisco, córrego das palmas, terreno de Roberto Strey, 23.XI.2000, fr., L. Kollmann \& E. Bausen 3382 (ESA, MBML). Castelo, propr. particular (Elias Fassine), 29.X.2012, fr., T.B. Flores \& O.R. Campos 1678 (ESA). Conceição do Castelo, Venda Nova, arredores, 17.X.1985, fl., G. Hatschbach \& J.M. Silva 49897 (INPA, MO). Ibitirama, Pedra Roxa, ao longo do Rio Pedra Roxa, 25.X.2012, T.B. Flores \& O.R. Campos 1561 (ESA). Linhares, Reserva Natural Vale, estrada do Guaribú Sabão, 22.X.2009, f1., D.A. Folli 6442 (ESA). Santa Teresa, Nova Lombardia, Res. Biol. Augusto Ruschi, picada após marco 82, 6.V.2003, fl., R.R. Vervloet \& W. Pizziolo 2356 (ESA, MBML). Sooretama, Reserva Biológica de Sooretama, 25.VIII.2012, fl., T.B. Flores \& G.O. Romão 1136 (ESA).

Os dados sobre floração e frutificação dessa espécie são escassos, mas provavelmente floresce entre junho e outubro e frutifica em junho, outubro e janeiro. Trichilia emarginata é facilmente distinta das demais espécies do gênero por apresentar a raque da folha estreitamente alada.

\subsection{Trichilia hirta L., Syst. Nat. 2: 1020. 1759.}

Fig. 4a-h

Árvores ou arbustos, 0,5-14 m de altura, gemas terminais com catafilos, densamente pubescentes, ramos jovens pubescentes, amadurecendo glabros. Folhas imparipinadas, 19-40 cm compr., pecíolo 2,5-7,5 cm compr., semicilíndrico a canaliculado, pubescente a glabro, sem projeções, raque semicilíndrica a canaliculada, pubescente a glabra. Folíolos 7-19, basais similares aos demais, alternos a opostos, peciólulo 1-20 mm, terminais muito maiores que os demais, lâmina 4-11 × 2-4,5 cm, oblonga, lanceolada a elíptica, ápice acuminado a emarginado, base aguda a atenuada, geralmente assimétrica, face abaxial pubescente, com tricomas simples concentrados nas nervuras e margem, algumas vezes com papilas vermelhas dispersas sobre a lâmina, face 


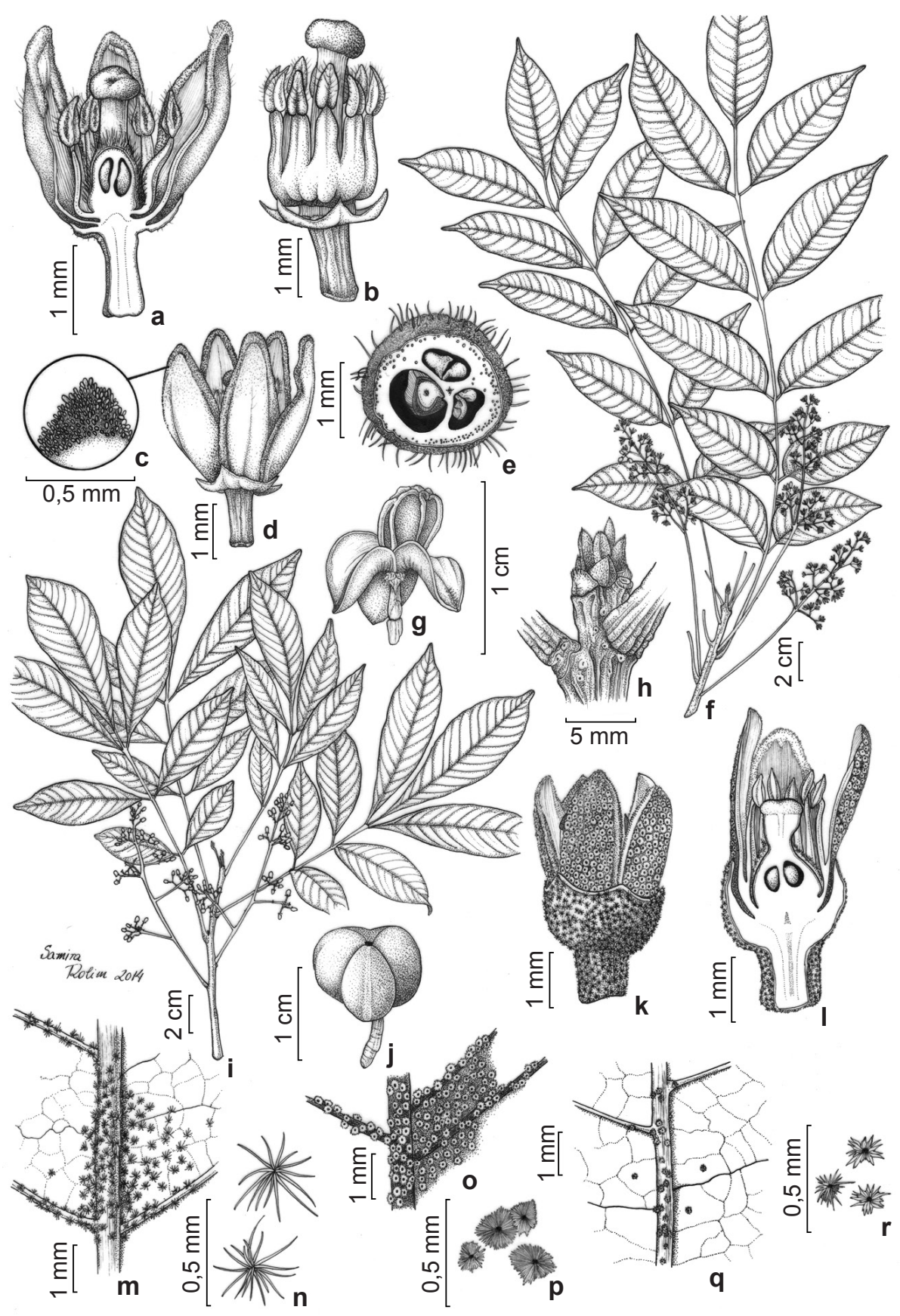

Figura 4 -a-h. Trichilia hirta - a. flor em corte longitudinal; b. tubo estaminal, vista externa; c. pétalas, detalhe das papilas no ápice; d. flor, vista externa; e. fruto imaturo em conte transversal; f. ramo florífero; g. fruto; h. folha, gemas terminais protegidas por catafilos. i,j. Trichilia pallens - i. ramo florífero; j. fruto. k-r. Trichilia lepidota - k. flor, vista externa; 1 . flor em corte longitudinal; $\mathrm{m}$. folíolo, detalhe do indumento da face abaxial; $\mathrm{n}$. tricoma estrelado; o. folíolo, detalhe do indumento da face abaxial; p. tricoma escamiforme pouco recortado; q. folíolo, detalhe do indumento da face abaxial; r. tricoma escamiforme profundamente recortado. (a-f. Folli 5736; g,h. Dan 2; i,j. Kuntz 847; k,1,o,p. Folli 6267; m,n. Flores 1526; q,r. Flores 222). Figure 4 - a-h. Trichilia hirta - a. flower, longitudinal view; b. staminal tube, external view; c. petal, detail of the papillae in the apex; d. flower, external view; e. immature fruit, transversal view; f. branch with flowers; g. fruit; h. terminal buds protected by cataphylls. i,j. Trichilia pallens -i. branch with flowers; j. fruit. k-r. Trichilia lepidota $-\mathrm{k}$. flower, external view; 1. flower, longitudinal view; $\mathrm{m}$. leaflet indumentum, detail in the abaxial surface; $n$. stellate hair; $o$. leaflet indumentum, detail in the abaxial surface; $p$. scale hair, less indented; $q$. leaflet indumentum, detail in the abaxial surface; r. scale hair deeply indented. (a-f. Folli 5736; g,h. Dan 2; i,j. Kuntz 847; k,1,o,p. Folli 6267; m,n. Flores 1526; q,r. Flores 222). 
adaxial esparsamente pubescente a completamente glabra, nervura principal proeminente na face abaxial e impressa ou proeminente na face adaxial, nervuras secundárias proeminentes na face abaxial e impressas ou proeminentes na face adaxial com domácias nas axilas das nervuras secundárias ou não, com pontuações e linhas translúcidas ou não. Inflorescências axilares, determinadas, compostas, com ramos laterais principalmente na região basal e central, ápice com flores solitárias, 10-21 cm compr., pubescentes. Flores alvas, pedicelo 0,5-1 mm compr., glabro ou com tricomas muito esparsos. Cálice gamossépalo, subemisférico, 4-5 lobos agudos, face interna glabra, face externa densamente papilosa. Corola imbricada, dialipétala, pétalas 5, 3-4 × 1-1,5 mm, oblongas a lanceoladas, face externa densamente papilosa e com tricomas longos e esparsos, face interna densamente papilosa. Estames com filetes parcialmente unidos, formado um tubo, 1-3 mm compr., face externa densamente papilosa e esparsamente pubescente, face interna densamente papilosa e com tricomas longos e irregularmente orientados na parte superior do tubo, ápice dos filetes com dois lobos arredondados nos lados das anteras e muito menores que essas. Anteras 10, 0,5-1 mm compr., densamente papilosas e pubescentes. Nectário anelar, glabro. Ovário 3-locular com 1-2 óvulos colaterais em lóculo, pubescente, estilete glabro, estigma capitado e papiloso. Cápsulas trigonais, base truncada, ápice agudo com um mucro, 4-11 × 4-9 mm, densamente papilosas com tricomas longos e esparsos, lisa, com 3 valvas, fortemente reflexas, sépalas não persistentes no fruto. Sementes 3-6 mm, globosas a levemente elipsoides, completamente recobertas por um arilo de coloração avermelhada.

Material selecionado: Águia Branca, assentamento 16 de abril, 16.III.2006, fr., V. Demuner et al. 2049 (ESA, MBML). Alegre, ARIE Laerth Paiva Gama, 9.II.2008, fr., A.M. Assis et al. 1386 (MBML). Barra de São Francisco, Boa Sorte, 13.VII.1984, fr., R.M. Pizziolo 196 (ESA, MBML, MO). Cachoeira de Itapemirim, fazenda de Rubens Barelli, 21.V.1991, fr., V. Souza 95 (CVRD, ESA). Castelo, Caxixe Quente, 18.V.1999, fr., G. Hatschbach et al. 69150 (MBML). Colatina, prop. Manoel (Neco) Zani, cascatinha do Pancas, 4.XII.2008, fl., A.M. Assis 1903 (ESA, MBML). Itapemirim, Fazenda do Ouvidor, Usina Paineiras, 14.III.2008, fr., A.M. Assis \& V.G. Demuner 1405 (ESA, MBML). Linhares, área experimental da Reserva Natural Vale, 19.III.2001, fr., D.A. Folli 3847 (CVRD, ESA). Nova Venécia, APA Pedra do Elefante. Serra de Baixo, fazenda Neblina, 13.I.2009, fr., L. Kollmann \& A.P. Fontana 11370
(MBML). Presidente Kennedy, propr. Ferrous, próximo à Praia das Neves, 27.IX.2009, fr., S. Maielo et al. 139 (RB). Santa Teresa, Convento da Penha, 10.X.2007, fl., D.A. Folli 5736 (CVRD, ESA). Vila Velha, 10.I.2001, fr., O.J. Pereira \& E. Espindula 6716 (ESA, VIES). Serra, loteamento Alphaville, rodovia do contorno, 28.III.2004, fr., A.M. Assis \& O.J. Pereira 1006 (ESA, MBML). Vitória, Parque Municipal da Fonte Grande, Vale Ganda, 5.II.2004, fr., M.L. Dan 2 (ESA, VIES).

Trichilia hirta floresce entre outubro e novembro e frutifica entre janeiro e julho. $\mathrm{O}$ reconhecimento dessa espécie, é realizado com base nas gemas terminais recobertas por catafilos, nos filetes dos estames parcialmente unidos, nas anteras pilosas e nos frutos trigonais.

\subsection{Trichilia lepidota Mart., Flora 22, Beibl. 1:54.} 1839.

Fig. 4k-r

Árvores, 6-25 m de altura, gemas terminais sem catafilos, tomentosas estreladas ou densamente lepidotas, persistente nos ramos jovens, amadurecendo glabros. Folhas imparipinadas, 13-65 cm compr., pecíolo 3-13 cm compr., canaliculado a achatado, tomentoso estrelado ou densamente lepidoto, sem projeções, raque canaliculada a achatada, tomentosa estrelada ou densamente lepidota. Folíolos 7-13, basais similares aos demais, opostos, peciólulo 3-15 mm compr., geralmente os apicais maiores que os demais, canaliculado, tomentoso estrelado ou densamente lepidoto, lâmina 4-25 × 2-7,5 cm, lanceolada, elíptica a oblonga, ápice acuminado a arredondado ou menos frequentemente emarginado, muitas vezes mucronado, base aguda a atenuada, face abaxial tomentosa estrelada ou densamente a esparsamente lepidota, face adaxial lepidota ou esparsamente pubescente com tricomas estrelados, nervura principal proeminente na face abaxial e sulcada na face adaxial, secundárias proeminentes na face abaxial e impressas na face adaxial, sem domácias, sem pontuações e linhas translúcidas. Inflorescências axilares, compostas, determinadas, com ramos laterais de primeira e segunda ordem, principalmente na base e região central da inflorescência, ápice com flores solitárias, 4-26 cm compr., tomentosas estreladas ou densamente lepidotas. Flores amarelas a alvas, pedicelo 2-3 mm compr., tomentoso estrelado ou densamente lepidoto. Cálice gamossépalo, subemisférico e irregularmente lobado com ápices agudos, tomentoso estrelado ou densamente lepidoto. Corola imbricada, dialipétala, pétalas 5, 3-4 × 1-2,5 mm, lanceoladas a oblongas, face externa 
tomentosa estrelada ou densamente lepidota, face interna papilosa principalmente no ápice e margens. Estames com filetes livre ou raramente fundidos na base, 1-2,5 mm compr., glabros, ápice dos filetes geralmente com dois lobos arredondados ou agudos nos lados das anteras e menores que essas. Anteras 8-10, glabras, 0,5-1,5 mm compr. Nectário anelar, fundido com a base do ovário. Ovário 3(-4)-locular, com 2 óvulos colaterais em cada lóculo, tomentoso estrelado ou densamente lepidoto, estilete esparsamente pubescente estrelado ou esparsamente lepidoto, estigma capitado e papiloso. Cápsulas globosas a elipsoides, raramente trigonais, base arredondada, truncada ou estipitada, ápice arredondado, truncado, apiculado ou extremamente rostrado, 5-22 × 5-11 mm, tomentosas com tricomas estrelados ou densamente lepidota, lisas, 3(-4) valvas, reflexas ou não, sépalas persistentes no fruto. Sementes 4-11 mm compr., elipsoides e parcialmente recobertas por um arilo vermelho alaranjado.

Material selecionado: Domingos Martins, 11.I.2001, fl., O.J. Pereira \& E. Espindula 6723 (ESA, VIES). Ibitirama, Pedra Roxa, estrada para o alojamento do ICMBIO, 25.X.2012, fr., T.B. Flores \& O.R. Campos 1526 (ESA). Linhares, Reserva Natural Vale, Estrada Juerana Falcão, no meio da subida, 27.VIII.2009, fr., T.B. Flores et al. 222 (ESA); 27.VIII.2009, fr., D.A. Folli 6400 (CVRD, ESA, NY); Estrada Mantegueira, 5.I.2009, fl., D.A. Folli 6267 (CVRD, ESA); Estrada Sapucaia Vermelha, 23.VIII.2004, fr., D.A. Folli 4905 (CVRD, ESA). Pancas, Estrada da Igreja, 23.III.2007, fr., A.A. Luz 384 (CVRD, ESA). Santa Teresa, Estação Biológica de Santa Lúcia, 25.III.2006, fr., F.Z. Saiter 265 (ESA, MBML); Rio Quinze de Agosto, propr. Giovani Pasolini, 26.VII.2000, fr., V. Demuner et al. 1268 (ESA, MBML); Vinte e Cinco de Julho, terreno do Fracalossi, 24.VI.1999, fr., L. Kollmann \& E. Bausen 2689 (ESA, MBML). São Domingos do Norte, trevo para Águia Branca, 3.V.2008, fr., A.M. Assis \& K.F.O. Faria 1633 (ESA, MBML). Venda Nova do Imigrante, Alto Bananal, 16.I.1995, fl., G. Hatschbach et al. 61547 (ESA, MBM, MO, RB). Vitória, Parque Municipal da Fonte Grande, 12.VIII.2004, fr., M.L. Dan 78 (ESA, VIES).

Trichilia lepidota foi coletada com flores entre os meses de novembro e janeiro e com frutos entre março e outubro. No Espírito Santo é facilmente reconhecida pelo indumento formado por tricomas estrelados ou escamiformes, geralmente presentes em diversas partes das plantas, especialmente nos ramos jovens e na face abaxial dos folíolos.

Quando analisadas as descrições e a chave de identificação das subespécies de T. lepidota apresentadas por Pennington (1981), observamos que a separação desses táxons é baseada no tipo dos tricomas que compõe o indumento das partes jovens da planta e inflorescência, no formato do ápice dos folíolos, no tamanho, forma do ápice e coloração do fruto quando seco, além do comprimento das anteras. No Espírito Santo, T. lepidota subsp. lepidota é facilmente reconhecida utilizando as informações acima, entretanto, as outras duas apresentam problemas na sua delimitação. Os materiais V. Demuner et al. 1268, L. Kollmann \& E. Bausen 2689 e D.A. Folli 6400 apresentam folíolos com ápice acuminado, fruto com menos de 1,3 $\mathrm{cm}$ de compr., ápice arredondado (algumas vezes mucronulado) e coloração castanho, o que poderia caracterizar esses materiais como T. lepidota subsp. leucastera (Sandwith) Penn. Entretanto, os tricomas que compõe o indumento das partes jovens e inflorescências são escamifomes e presentes na outra subespécie - T. lepidota subsp. schumanniana (Harms) T.D. Penn. Os materiais M.L. Dan 78 e D.A. Folli 4905, apresentam a mesma delimitação morfológica, além de apresentarem frutos maiores e menores que $1,3 \mathrm{~cm}$ de comprimento.

Já o material T.B. Flores 1526 apresenta tricomas estrelados compondo o indumento das partes jovens e inflorescências, frutos com ápice truncado, com coloração ferrugínea e maiores ou menores que 1,3 cm de comprimento. Outra dificuldade na separação das subespécies diz respeito à medida do comprimento das anteras, visto que, a separação é baseada em uma diferença menor que 0,5 mm. Além disso, a distinção das subespécies, quando analisados espécimes que apresentam apenas flores femininas não é possível, já que a única informação disponível na descrição e chave é o comprimento das anteras. Assim, foi considerado que a divisão em subespécies de $T$. lepidota, como proposto por Pennington (1981) não é adequada e que uma revisão taxonômica para o grupo é necessária.

4.7. Trichilia magnifoliola T.D. Penn., Fl. Neotrop. Monogr. 28: 185. 1981.

Fig. 5c,d

Árvores ou arbustos, 3-7 m de altura, gemas terminas sem catafilos, densamente velutinas, ramos pubescentes. Folhas imparipinadas, 36-55 cm compr., pecíolo 7-13 cm compr., canaliculado, densamente pubescente, sem projeções, raque canaliculada, densamente pubescente. Folíolos 7-10, basais similares aos demais, alternos, peciólulo 3-5 $\mathrm{mm}$ compr., canaliculado, pubescente, lâmina 10-28 × 4-9,5 cm, elíptica a obovais, ápice agudo, raramente emarginado, base atenuada, face abaxial densamente pubescente, 
face adaxial densamente pubescente com tricomas simples principalmente concentrados nas nervuras e margem, nervura principal proeminente na face abaxial e inclusa na face adaxial, nervuras secundárias proeminentes na face abaxial, inclusas na face adaxial, sem domácias, sem pontuações e linhas translúcidas. Inflorescências axilares, fasciculadas, indeterminadas, com 3 longos eixos principais partindo da base da inflorescências, eixos determinados, com ramificações de primeira e segunda ordem, 3-12 cm compr., densamente pubescentes. Flores amarelas a alvas, pedicelo 2-3 mm compr., pubescente. Cálice gamossépalo, subemisférico e irregularmente lobado, densamente pubescente. Corola valvar, gamopétala, pétalas $5,5-7 \times 1-2,5 \mathrm{~mm}$, lanceoladas, face externa densamente pubescente, face interna densamente papilosa. Estames com filetes completamente unidos formando um tubo, 3-5 $\mathrm{mm}$ compr., glabro, ápice dos filetes com dois lobos agudos nos lados das anteras e muito menores que essas. Anteras 10, 0,5-1 mm compr., papilosas, dispostas em diferentes alturas no ápice do tubo. Nectário ausente. Ovário 3-locular, com 2 óvulos colaterais em cada lóculo, densamente pubescente, estilete glabro, estigma capitado, glabro ou papiloso. Cápsulas elipsoides a ovaladas, base truncada, ápice agudo, 20-26 × 12-14 mm, densamente pubescente, lisa, três valvas, não reflexas, sépalas não persistentes nos frutos. Sementes 20-22 mm compr., completamente recobertas por um arilo vermelho.

Material selecionado: Águia Branca, Águas Claras, prop. Zequinha, 7.VI.2006, fr., V. Demuner et al. 2478 (ESA, MBML). Cachoeira de Itapemirim, estrada para Itabira, 25.IV.1972, fl., D. Sucre \& T. Soderstrom 8948 (ESA, RB). Colatina, Alto Moacir, Pedra do Cruzeiro, prop. Landislau, 17.IV.2006, fl., L.F.S. Magnago et al. 788 (ESA, MBML). Governador Lindenberg, Santa Luzia, Firmino, 2.VIII.2007, fl., R.R. Vervloet et al. 3150 (ESA, MBML). Marilândia, Alto Liberdade, prop. Deucleio Lorenzini, 19.IV.2006, fl., L.F.S. Magnago et al. 901 (MBML). São Domingos do Norte, Próx. Sede (Torre 57/1 - LT 230 Kv Mascarenhas x Verona), 23.V.2008, f1., A.M. Assis \& K.F.O. Faria 1688 (ESA, MBML). Santa Leopoldina, Colina Verde (Morro do Agudo), prop. Israel Elias Ramos, 31.V.2007, fl., V. Demuner et al. 4161 (ESA, MBML). Santa Teresa, Margem do Rio Sta. Ma. Rio Doce, prop. Ervídeo Hortelã, 16.VII.2003, fl., A.M. Assis et al. 962 (ESA, MBML).

Trichilia magnifoliola foi coletada com flores entre os meses de fevereiro a agosto, e frutos entre os meses de julho a novembro. A distinção de T. magnifoliola das demais espécies é realizada com base nas folhas compostas com folíolos basais similares aos demais, face abaxial dos folíolos com indumento formado por tricomas simples, inflorescências fasciculadas com ramos laterais longos e corola com prefloração valvar. O grande número de nervuras secundárias, paralelas e próximas entre si também é útil para o reconhecimento dessa espécie.

4.8. Trichilia pallens C. DC., in Mart., Fl. bras. 11(1): 218. 1878.

Fig. $4 \mathrm{i}, \mathrm{j}$

Árvores ou arbustos, 2-8 m de altura, gemas terminais sem catafilos, densamente velutinas, ramos jovens estrigosos, amadurecendo glabros. Folhas imparipinadas, 13-34 cm compr., pecíolo 6-13 cm compr., semicilíndrico, estrigoso, sem projeções, raque semicilíndrica a achatada, estrigosa, intercalando tricomas adpressos com papilas avermelhadas. Folíolos 5-9, basais similares aos demais, opostos a subopostos, peciólulo 3-14 mm compr., canaliculado, estrigoso, lâmina 10-15 $\times 2,5-4,5 \mathrm{~cm}$, lanceolada, oblonga, oboval, ápice acuminado, algumas vezes curtamente mucronado, base atenuada, geralmente decorrente, face abaxial esparsamente estrigosa ou pubescente sobre as domácias, com papilas grandes, vermelhas e esparsas, face adaxial glabra com papilas grandes, vermelhas e esparsas, nervura principal proeminente em ambas as faces, nervuras secundárias impressas a levemente proeminentes em ambas as faces, com domácias nas axilas das nervuras secundárias, pontuações e linhas translúcidas inconspícuas ou ausentes. Inflorescências axilares, determinadas, compostas, com ramificações de primeira e segunda ordem principalmente na região basal e central, ápice com flores solitárias, $5-11 \mathrm{~cm}$, esparsamente estrigosas. Flores creme a alvas, pedicelo 1-2 $\mathrm{mm}$, estrigoso a esparsamente pubescente. Cálice gamossépalo, subemisférico e irregularmente lobado, com ápices agudos ou sépalas unidas apenas nas bases, lanceoladas a triangulares, densamente estrigosas. Corola imbricada, dialipétala, pétalas 5,3-3,5 × 1-2 mm, oblongas a lanceoladas, face externa densamente estrigosa e papilosa, face interna densamente papilosa, com tricomas concentrados nas margens e ápice. Estames com filetes completamente unidos formando um tubo, 2-3 mm compr., parte superior da face externa densamente pubescente, intercalando tricomas longos e papilosos, parte superior da face interna com tricomas longos irregularmente orientados, ápice do tubo com lobos alternos com as anteras e muito menores que essas. 
Anteras 8-10, densamente papilosas e pubescentes. Nectário anelar. Ovário 3-locular, com 2 óvulos colaterais em cada lóculo, glabro, estilete glabro, estigma discoide a trilobado. Cápsulas globosas a trigonais, base truncada a curtamente estipitada, ápice truncado, arredondado a emarginado, 11-17 $\times$ 9-15 mm, densamente papilosas e pubescentes, lisas, 3 valvas, reflexas, sépalas persistentes no fruto. Sementes 6-8 mm compr., elipsoides, parcialmente recobertas por um arilo vermelho.

Material selecionado: Alegre, Parque Estadual da Cachoeira da Fumaça, área Maria Luiza Campagnaro, 12.I.2011, fr., M.M. Azevedo et al. 454 (RB). Castelo, Parque Estadual do Forno Grande, 27.I.2004, fr., $L$. Kollmann 6375 (ESA, MBML). Dores do Rio Preto, Parque Nacional do Caparaó, estrada entre a entrada do parque e o centro de Pedra Menina, 21.X.2012, fr., T.B. Flores et al. 1402 (ESA); Pedra Menina, Parque Nacional do Caparaó, 13.I.2013, fl., J. Kuntz \& G.D. Colletta 847 (ESA, HUEMG). Ibitirama, Santa Marta, propr. abandonada, depois do sítio da Jacutinga e antes do sítio do Alemão (Cláus - Diva), trilha atrás das ruínas da casa, 25.X.2012, fl., T.B. Flores \& O.R. Campos 1553 (ESA).

Foram analisados espécimes coletados com flores em janeiro e outubro e com frutos em janeiro, março a maio, e outubro. Trichilia pallens é correlacionada com T. elegans e a distinção dessas espécies pode ser realizada com base na densidade das pontuações e linhas translúcidas das folhas (muito evidentes em T. elegans) e no indumento da face externa das pétalas e anteras (exclusivamente papiloso em T. elegans).

\subsection{Trichilia pallida Sw., Prodr. 67. 1788.}

Fig. 5e-g

Árvores ou arbustos, 5-8 m de altura, gemas terminais sem catafilos, densamente velutinas, ramos jovens estrigosos, amadurecendo glabros. Folhas trifolioladas ou imparipinadas, $11-35 \mathrm{~cm}$ compr., pecíolo 2-5,5 cm compr., canaliculado, pubescente, sem projeções, raque achatada a canaliculada, pubescente. Folíolos 3-7, basais similares aos demais, opostos a subopostos, peciólulo 2-5 mm compr., canaliculado, pubescente, lâmina 5-20 × 2,5-6,5 cm, elíptica, oblonga, lanceolada a oboval, ápice acuminado, base atenuada, face abaxial glabra ou pubescente com tricomas com concentrados nas nervuras, face adaxial glabra, nervura principal proeminente em ambas as faces, nervuras secundárias proeminentes em ambas as faces, sem domácias, sem pontuações e estrias translúcidas. Inflorescências axilares, fasciculadas, 1,5-3,5 cm compr., densamente pubescentes. Flores alvas a creme, pedicelo 2-3 mm compr., pubescente. Cálice gamossépalo, subemisférico e irregularmente lobado com ápices agudos, densamente pubescente. Corola imbricada, dialipétala, pétalas $4-5,5-7 \times 1-2,5 \mathrm{~mm}$, oblongas a elípticas, face externa papilosa e estrigosa, face interna densamente papilosa. Estames com filetes parcialmente unidos formando um tubo, 3-3,5 $\mathrm{mm}$ compr., ápice do filetes com dois apêndices filiformes ao lado das anteras e maiores ou do mesmo tamanho que essas. Anteras 8, 0,5-1,5 $\mathrm{mm}$ compr., papilosas ou com tricomas esparsos. Nectário anelar na base do ovário e, algumas vezes unido à base do tubo estaminal, glabro. Ovário 3-4-locular, com 2 óvulos sobrepostos em cada lóculo, densamente pubescente, estilete híspido, estigma capitado e papiloso. Cápsulas globosas a trigonais, base arredondada, ápice mucronado, 6-13 $\times 8-10 \mathrm{~mm}$, densamente papilosas e pubescentes, lisas, 3-4 valvas, reflexas, sépalas persistentes nos frutos. Sementes 6-8 $\mathrm{mm}$ compr., recoberta parcialmente por um arilo avermelhado.

Material examinado: Alegre, ARIE Laerth Paiva Gama, 25.VII.2008, fr., D.R. Couto et al. 732 (ESA, MBML). Baixo Guandú, estrada Ibituba a Córrego Lage, 6.V.2009, fr., A.A. Luz 505 (CVRD, ESA). Cachoeira de Itapemirim, 22.IV.2008, fl., L. Kollmann \& L. Magnago 11003 (MBML). Ibitirama, Parque Cachoeira da Fumaça, 10.VI.2008, fr., D.A. Folli 6089 (CVRD, ESA, NY). Linhares, Reserva Natural Vale, aceiro Bobbio, 4.VI.2008, fr., D.A. Folli 6076 (CVRD, ESA). Mimoso do Sul, rodovia às margens do Rio Itabapoana, divisa com o Rio de Janeiro, 16.VII.2008, fr., R.A.X. Borges et al. 910 (RB).

Trichilia pallida é frequentemente encontrada em grande número de indivíduos muitas vezes férteis, principalmente em áreas perturbadas. No Espírito Santo essa espécie foi encontrada com flores entre os meses de janeiro e julho e frutos entre maio e agosto. As inflorescências fasciculadas, os estames com filetes parcialmente unidos formando um tubo, com ápices providos de apêndices filiformes maiores que as anteras ou com aproximadamente o mesmo tamanho e o ovário com 2 óvulos sobrepostos por lóculo, possibilitam a distinção dessa espécie das outras do gênero.

4.10. Trichilia pseudostipularis (A. Juss.) C. DC., in Mart., Fl. bras. 11(1):215. $1878 . \quad$ Fig. 5a,b Árvores ou arbustos, 1-5 m de altura, gemas terminais sem catafilos, estrigosas ou velutinas. Folhas imparipinadas, $13-56 \mathrm{~cm}$ compr., pecíolo 2-4 mm compr., cilíndrico, pubérulo, sem projeções, raque canaliculada a cilíndrica, glabra a pubérula. Folíolos 5-11, par basal com forma e tamanho muito diferente dos demais $(0,7-5 \times 0,8-5 \mathrm{~cm}$, ovais, base 


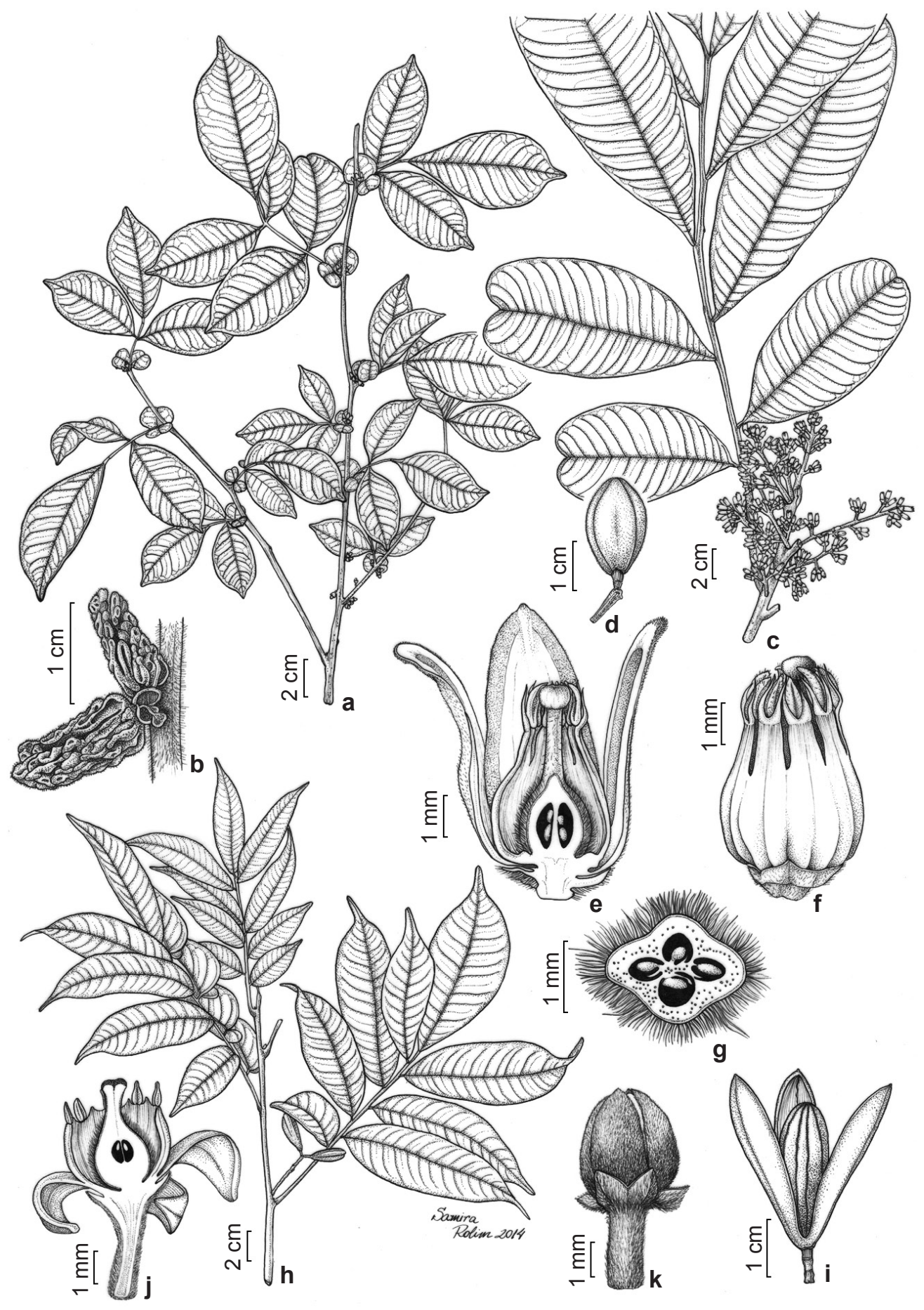

Figura 5 - a,b. Trichilia pseudostipularis - a. ramo florífero; b. frutos. c,d. Trichilia magnifoliola - c. ramo florífero; d. fruto. e-g. Trichilia pallida - e. flor em corte longitudinal; f. vista externa do tubo estaminal; g. ovário em corte transversal. h-k. Trichilia quadrijuga - h. ramo frutífero; i. fruto; j. flor em corte transversal; k. vista externa do botão floral. (a. Folli 5257; b. Demuner 3040; c. Demuner 4161; d. Demuner 2478; e-g. Folli 6076; h,i. Folli 383; j,k. Folli 363).

Figure 5 - a-b. Trichilia pseudostipularis - a. branch with flowers; b. fruits. c,d. Trichilia magnifoliola - c. branch with flowers; $d$. fruit. e-g. Trichilia pallida - e. flower, longitudinal view; f. staminal tube, external view; g. ovary, transversal view. h-k. Trichilia quadrijuga - h. branch with fruits; i. fruit; j. flower, transversal view; k. flower bud, external view. (a. Folli 5257; b. Demuner 3040; c. Demuner 4161; d. Demuner 2478; e-g. Folli 6076; h,i. Folli 383; j,k. Folli 363). 
fortemente assimétrica, dispostos a semelhança de duas estípulas - pseudoestípulas), opostos ou alternos, peciólulo 0-6mm compr., lâmina 6-33 $\times$ 2,5-13,5 cm, elíptica, lanceolada, base aguda, arredondada a cordada, muitas vezes assimétrica, ápice acuminado, face abaxial glabra, glabrata com tricomas adpressos ou raramente pubescente, face adaxial glabra, glabrata ou raramente pubescente na nervura principal, nervura principal proeminente na face abaxial e impressa ou sulcada na face adaxial, nervuras secundárias levemente proeminentes em ambas as faces, sem domácias e pontuações translúcidas. Inflorescências axilares, ramifloras ou caulifloras, fasciculadas, algumas vezes com apenas uma ou duas flores por inflorescência, 0,5-2 cm compr., pubérulas a estrigosas. Flores creme a alvas, pedicelo 0-1 mm compr., glabro a esparsamente pubescente. Cálice gamossépalo, subemisférico e irregularmente lobado com ápice agudo, glabro a pubescente. Corola valvar, gamopétala, pétalas unidas na região mediana ou no terço inferior, pétalas 3-5, 3-4 × 0,5-1 $\mathrm{mm}$, lanceoladas, face externa papilosa, algumas vezes intercaladas com indumento estrigoso, face interna densamente papilosa. Estames com filetes completamente unidos formando um tubo, 2-3 mm compr., face externa papilosa e pubescente, face interna papilosa e com tricomas longos e irregularmente orientados, ápice do tubo 5-8 apêndices filiformes, alternos com as anteras e menores que essas. Anteras 5-8, papilosas, 0,5-1 mm compr. Nectário ausente. Ovário 3-locular, com 2 óvulos colaterais em cada lóculo, densamente pubescente, com tricomas adpressos, estilete glabro, estigma discoide e papiloso. Cápsulas oblongas a elipsoides, base truncada, ápice agudo a arredondado, mucronado, $12-22 \times 6-12 \mathrm{~mm}$, densamente papilosas e pubescentes com tricomas concentrados na base, lisas a verrucosas, 3 valvas, não reflexas, sépalas persistentes no fruto. Sementes 11-14 mm compr., elipsoide e parcialmente recoberta por um arilo vermelho.

Material selecionado: Águia Branca, Córrego Jabuticaba, propr. Rosangela Fausti, 30.XI.2006, fr., L.F.S. Magnago et al. 1667 (MBML). Cachoeira de Itapemirim, estrada para Itabira, 25.IV.1972, fl., D. Sucre \& T. Soderstrom 8958 (ESA, RB). Governador Lindemberg, Morelo, propr. Fernando Nicolli, 13.XI.2006, fr., V. Demuner et al. 3040 (ESA, MBML). Linhares, Reserva Natural Vale, Estrada Guaribú Sabão, 25.IV.2006, fl. e fr., D.A. Folli 5257 (CVRD, ESA), Reserva Natural Vale, Estrada da Mantegueira, 20.X.2010, fl., T.B. Flores \& G. Siqueira 887 (ESA). Nova Venécia, Área de Proteção Ambiental Pedra do Elefante, Serra de Baixo, 10.V.2008, fl.,
São-Mateus et al. 6 (ESA, RB). Santa Teresa, Escola Agrotécnica Federal de Santa Teresa, 12.V.1999, W.P. Lopes et al. 705 (ESA, MBML). São Matheus, Reserva Biológica de Sooretama, Lagoa do Macaco, 15.V.1977, fl., G. Martinelli et al. 2211 (ESA, RB). Sooretama, Reserva Florestal de Sooretama, 17.VIII.1969, fr., D. Sucre 5696 (ESA, RB).

Trichilia pseudostipularis apresenta flores e frutos em quase todos os meses do ano e algumas vezes, simultaneamente. Essa espécie é facilmente distinta das outras espécies do gênero por apresentar um par de folíolos basais com forma e tamanho diferentes dos demais e posicionados de modo semelhante a um par de estípulas (pseudoestípulas). Além disso, as inflorescências fasciculadas curtas também auxiliam na sua distinção.

4.11. Trichilia quadrijuga Kunth, in Humboldt, Bonpland \& Kunth, Nov. Gen. Sp. 5:215. 1822.

Fig. 5h-k

Árvores, 15-22 m de altura, gemas terminais sem catafilos, densamente pubescentes, formado principalmente por tricomas dibraquiados, ramos jovens amadurecendo glabros. Folhas imparipinadas ou paripinadas com um dos folíolos do par apical simulando um folíolo terminal, 9-25 cm compr., pecíolo 0,8-2 cm compr., semicilíndrico a canaliculado, densamente pubescente, intercalando tricomas papilosos, dibraquiados e longos tricomas adpressos, sem projeções, raque canaliculada recoberta pelo mesmo tipo de indumento do pecíolo. Folíolos 7-10, além de um par basal vestigial (lineares, 1-2 $\mathrm{mm}$ compr. e geralmente precocemente caduco), geralmente alternos, raramente opostos, peciólulo $0,5-2 \mathrm{~mm}$, base fixa ou raramente peltada, pubescente, intercalando tricomas dibraquiados e longos tricomas adpressos, lâmina 2,5-12 × 1,5-6 cm, lanceolada, oblonga a elíptica, ápice truncado a acuminado, mucronado, base aguda a atenuada, algumas vezes cordada ou arredondada, face abaxial glabrata a pubescente com tricomas simples e dibraquiados concentrados nas nervuras, face adaxial glabra a pubescente sobre as nervuras, nervura principal proeminente na face abaxial e sulcada na face adaxial, nervuras secundárias proeminentes na face abaxial e impressas na face adaxial, sem domácias e pontuações translúcidas. Inflorescências axilares, determinadas, compostas, com ramos laterais nas regiões basal e central, ápice com flores solitárias, 4-13,5 cm compr., densamente pubescentes, intercalando tricomas simples e adpressos com dibraquiados. Flores alvas, pedicelo $0,5-1,5 \mathrm{~mm}$ compr., densamente 
pubescente, intercalando tricomas simples e adpressos com dibraquiados. Cálice gamossépalo, subemisférico e irregularmente lobado, face interna glabra, face externa densamente pubescente, intercalando tricomas simples e adpressos com dibraquiados. Corola valvar, dialipétala, pétalas 4-5, 2-3 $\times 1-2 \mathrm{~mm}$, oblongas a lanceoladas, face externa densamente pubescente, intercalando tricomas papilosos, longos tricomas simples e adpressos e tricomas dibraquiados, face interna densamente papilosa. Estames com filetes completamente unidos formando um tubo, 1,5-3 mm compr., densamente papiloso, ápice do tubo com apêndices filiformes alternados com as anteras e menores ou com aproximadamente o mesmo tamanho dessas. Anteras 8-10, 0,5-1 mm compr., densamente papilosas. Nectário ausente. Ovário 3-4-locular, com 2 óvulos colaterais em cada lóculo, densamente pubescente, estilete glabro, estigma capitado a discoide, glabro. Cápsulas elipsoides a oblongas, base aguda, ápice arredondado e mucronado, 20-35 $\times 8-11 \mathrm{~mm}$, densamente pubescentes com tricomas adpressos principalmente concentrados na base, região mediana e ápice pubescentes com tricomas papilosos, simples e adpressos ou dibraquiados, lisas, 3 valvas, não reflexas, sépalas não persistentes no fruto. Sementes 2-2,2 cm compr., elipsoides e completamente recobertas por um arilo vermelho. Material selecionado: Linhares, Reserva Florestal de Linhares - CVRD, 20.IV.1983, fr., A.L. Peixoto et al. 1737 (ESA, RB); próximo à Estrada 221, talhão 201, 2.XII.1972, fl., J. Spada 116 (RB); Estrada Farinha Seca, 26.II.1982, fl., D.A. Folli 363 (CVRD, ESA); 12.VIII.1982, fr., D.A. Folli 383 (CVRD, ESA); Estrada Jueirana Vermelha, 25.V.2006, fr., D.A. Folli 5284 (CVRD, ESA).

Trichilia quadrijuga aparentemente floresce no início do ano e frutifica entre maio a agosto. Essa espécie, pode ser distinta das demais por apresentar um par de folíolos basais vestigiais, face abaxial dos folíolos com tricomas dibraquiados, e frutos e sementes com $20 \mathrm{~mm}$ compr. ou mais.

4.12. Trichilia ramalhoi Rizzini, Leandra 4/5: 11. 1974.

Árvores, 15-25 m de altura, gemas terminais sem catafilos, tomentosas, ramos jovens tomentosos, amadurecendo glabros. Folhas imparipinadas, 7-23 cm compr., pecíolo $2-10 \mathrm{~mm}$ compr., cilíndrico a canaliculado, tomentoso, sem projeções, raque achatada a canaliculada, tomentosa. Folíolos 5-10, par basal com forma e tamanho muito diferentes dos demais $(2-2,5 \times 0,8-1,2 \mathrm{~cm}$, ovais a clavados, com base fortemente assimétrica, algumas vezes filiformes a vestigiais, caducos ou não), alternos a opostos, peciólulo $0-4 \mathrm{~mm}$, canaliculado, tomentoso, lâmina 5-10 × 2-4 cm, elíptica, oblonga, lanceolada, raramente clavada, ápice acuminado a arredondado mucronado, base aguda a atenuada, raramente cordada, face abaxial tomentosa com tricomas concentrados principalmente sobre as nervuras, face adaxial esparsamente pubescente com tricomas concentrados principalmente sobre as nervuras, nervura principal sulcada sulcadas na face adaxial e proeminente na face abaxial, nervuras secundárias sulcadas na face adaxial $\mathrm{e}$ proeminentes na face abaxial, sem domácias e pontuações translúcidas. Inflorescências axilares, compostas, determinadas, com ramos de primeira e segunda ordem na região basal, ápice com flores solitárias, 2,5-4 cm compr., tomentosas. Flores alvas a creme, pedicelo $2-3 \mathrm{~mm}$ compr., tomentoso. Cálice gamossépalo, subemisférico, lobado com ápice agudo, tomentoso. Corola valvar, gamopétala, pétalas unidas apenas na base, pétalas 4-5, 4-5,5 $\times 1-3 \mathrm{~mm}$, lanceoladas, face externa tomentosa e papilosa, face interna densamente papilosa. Estames com filetes completamente unidos formando um tubo, 3-4 mm compr., densamente papiloso, ápice do tudo com apêndices filiformes intercalados com as anteras e um pouco menores que essas. Anteras 8-10, 0,5-1,5 mm compr., papilosas. Nectário ausente. Ovário 3-locular, com 2 óvulos colaterais em cada lóculo, tomentoso, estilete glabro, estigma capitado, glabro ou papiloso. Cápsulas globosas a ovoides, ápice e base arredondados, 15-25 × 7-18 $\mathrm{mm}$, tomentosas, lisas, 3 valvas, não reflexas, sépalas não persistentes no fruto. Sementes 8-10 $\mathrm{mm}$ compr. e completamente revestida por um arilo vermelho.

Material examinado: Baixo Guandú, 30.VI.2004, fr., A.A. Luz 205 (CVRD, ESA). Linhares, Reserva Natural Vale, Estrada Farinha Seca, 18.XII.2008, fr., D.A. Folli 6265 (CVRD, ESA).

Material adicional examinado: BRASIL. BAHIA: Una, Reserva Biológica de Una, entrada no Km 46 da Rodovia BA-001, 23.V.1999, fl., J.G. Jardim et al. 2151 (ESA, RB). RIO DE JANEIRO: Rio de Janeiro, Horto Florestal, 1.II.1927, fl., J.G. Kuhlmann 606 (RB, ESA).

No Espírito Santo foram encontrados apenas dois espécimes nos municípios de Baixo Guandú e Linhares. Os dois materiais foram coletados com frutos em julho e dezembro. Já os materiais adicionais examinados indicam que a floração possivelmente ocorre no primeiro semestre do ano. Trichilia ramalhoi pode ser distinta com base no indumento tomentoso das partes jovens das plantas e na face abaxial dos folíolos. 
4.13. Trichilia silvatica C. DC., in Mart., Fl. bras. 11(1): 212.1878.

Árvores, 4-12 m de altura, gemas terminais sem catafilos, densamente estrigosas, intercalando tricomas simples e dibraquiados. Folhas imparipinadas, 16-25 cm compr., pecíolo 1,9-3,2 cm compr., canaliculado a semicilíndrico, pubérulo a estrigoso, intercalando tricomas simples e dibraquiados, sem projeções, raque canaliculada a achatada, acompanhando o indumento do pecíolo a completamente glabra. Folíolos 5-7, basais similares aos demais, alternos a subopostos, peciólulo 3-5 $\mathrm{mm}$, canaliculado, estrigoso, intercalando tricomas simples e dibraquiados, lâmina 5-12 × 3-6 cm, elíptica a oblonga, ápice acuminado, base atenuada, face abaxial glabrata próximo as nervuras com tricomas dibraquiados ou densamente pubérula sobre a nervura principal, face adaxial glabra, nervura principal proeminente em ambas as faces, secundárias proeminentes na face abaxial e impressas na face adaxial, sem domácias ou pontuações translúcidas. Inflorescências axilares, determinadas, compostas, com ramos de primeira e segunda ordem na região basal e mediana, ápice com flores solitárias, $2-10 \mathrm{~cm}$ compr., densamente pubérulas, intercalando tricomas simples e dibraquiados. Flores amarelas a alvas, pedicelo 1-2,5 mm compr., pubérulo, intercalando tricomas simples e dibraquiados. Cálice gamossépalo, subemisférico e irregularmente lobado com ápice agudo, acompanhando o indumento do pedicelo. Corola valvar, dialipétala ou unidas apenas na base, pétalas $5,1,5-2,5 \times 1-2 \mathrm{~mm}$, lanceoladas a triangulares, face externa densamente papilosa, com tricomas simples adpressos e dibraquiados, face interna densamente papilosa. Estames com filetes completamente unidos formando um tubo, 1-2 mm compr., face externa do tubo densamente papilosa, face interna densamente papilosa e com longos tricomas irregularmente orientados na parte superior, ápice do tubo formado por 7-8 apêndices filiformes intercalados com as anteras e com aproximadamente a metade do tamanho dessas. Anteras 7-8, papilosas, 0,5-1 mm compr. Nectário ausente. Ovário 3-locular, com 2 óvulos colaterais em cada lóculo, densamente pubescente, com tricomas adpressos, estilete glabro, estigma capitado a trilobado, glabro ou papiloso. Cápsulas oblongas, base truncada a curtamente estipitada, ápice arredondado, $12-20 \times 8-12 \mathrm{~mm}$, densamente papilhosas com tricomas simples adpressos e dibraquiados, na base densamente estrigosa, lisa, 3 valvas, não reflexas, sépalas não persistentes no fruto. Sementes 8-11 mm compr., elipsoide, completamente recoberta por um arilo vermelho. Material selecionado: Linhares, Reserva Florestal da CVRD, aceiro com Calimã, após a Estrada Caingá, 22.XI.1993, fr., D.A. Folli 2087 (CVRD, NY, RB, UEC); Reserva Natural Vale do Rio Doce, próximo à Estrada 142, talhão 402, 23.III.1973, fl., J. Spada 224 (ESA, RB); aceiro Catelã João Pedro, 21.III.2008, fr., D.A. Folli 5979 (CVRD, ESA); Estrada Caingá, 4.V.1999, fl., D.A. Folli 3413 (CVRD, ESA); Trilha do Pequi Vinagreiro, 22.X.2010, fr., T.B. Flores \& G. Siqueira 902 (ESA).

Trichilia silvatica foi coletada com flores nos meses de março e maio e com frutos nos meses de março, outubro e novembro. Essa espécie pode ser confundida com T. quadrijuga, entretanto, o número de folíolos, o indumento da face adaxial e tamanho do fruto ( $7-12$ folíolos, face adaxial pubescente, frutos 20-35 mm compr. - $T$. quadrijuga), logo as distinguem.

4.14. Trichilia tetrapetala C. DC., in Mart. Fl. bras. 11(1): 211. 1878.

Árvores ou arbustos, 5-12 $\mathrm{m}$ de altura, gemas terminais sem catafilos, densamente estrigosas, intercalando tricomas simples adpressos e dibraquiados. Folhas imparipinadas ou paripinadas com um dos folíolos do ápice simulando o terminal, 6-13 cm compr., pecíolo $2-5 \mathrm{~mm}$ compr., cilíndrico a canaliculado, intercalando um grande número de pequenos tricomas eretos com longos tricomas dibraquiados, sem projeções, raque canaliculada a achatada, com indumento similar ao do pecíolo. Folíolos 7-9, par basal muito diferentes dos demais $(2-13 \times 3-9 \mathrm{~mm}$, clavados, ovoides a largo elípticos, com base extremamente assimétrica), geralmente alternos, raramente opostos, sésseis ou com peciólulo de até $3 \mathrm{~mm}$, canaliculado, indumento similar ao da raque, lâmina 3-7 × 1,2-3 cm, oblonga a elíptica, ápice acuminado, raramente emarginado, base atenuada a decorrente, face abaxial glabrata a pubescente com tricomas simples e eretos ou longos e dibraquiados concentrados nas nervuras, face adaxial glabra ou glabrata próximo a base e margem, nervura principal proeminente na face abaxial e sulcada ou proeminente na face adaxial, nervuras secundárias proeminentes em ambas as faces, sem domácias e pontuações translúcidas. Inflorescências axilares, determinadas, compostas, com ramificações de primeira e segunda ordem na base e região central, 1-4 cm compr., esparsamente pubérulas, intercalando tricomas simples e dibraquiados. Flores creme a alvas, pedicelo 1-2 mm compr., glabro ou glabrato. Cálice 
gamossépalo, subemisférico e irregularmente lobado com ápice agudo, glabro ou glabrato. Corola valvar, gamopétala, muitas vezes unidas apenas na base, pétalas $4-5,1-2,5 \times 0,5-1,5 \mathrm{~mm}$, lanceoladas a triangulares, face externa densamente papilosa, intercalada ou não com poucos tricomas adpressos e dibraquiados, face interna densamente papilosas. Estames com filetes completamente unidos formando um tubo, 1,5-2 mm compr., face externa glabra, face interna com longos tricomas irregularmente orientados, ápice do tubo com 8-10 apêndices filiformes alternos com as anteras e com aproximadamente a metade do tamanho dessas. Anteras 8-10, papilosas, 0,5-1 mm compr. Nectário ausente. Ovário 3-locular, com 2 óvulos colaterais em cada lóculo, densamente pubescente, com tricomas adpressos, estilete glabro, estigma capitado a trilobado, papiloso. Cápsulas elipsoides a oblongas, base aguda, ápice arredondado mucronado, $15-18 \times 5-8 \mathrm{~mm}$, base da cápsula densamente pubescentes, região mediana e ápice densamente papilosas com tricomas simples e dibraquiados, lisa, 3 valvas, não reflexas, sépalas não persistentes no fruto. Sementes $11-15 \mathrm{~mm}$ compr., elipsoides e completamente recobertas por um arilo vermelho.

Material selecionado: Alegre, Parcela 8, 28.I.2009, fl., V.C. Manhães et al. 209 (ESA, MBML). Cachoeira de Itapemirim, Vargem Alta, 26.XII.1949, fl., M. Moreira \& Dominique (ESA 126244, RB 68385). Linhares, Reserva Florestal de Linhares - CVRD, próximo à Estrada 221, talhão 203, 4.XII.1972, fl., J. Spada 119 (RB). Mimoso do Sul, Morro Bom Retiro, 23.IV.1972, fr., D. Sucre \& T. Soderstrom 8894 (ESA, RB). Piúma, Ilha do Francês, 26.X.2002, fr., H. Pinheiro et al. 45 (VIES). Santa Teresa, Vargem Alegre, Cachoeira do Madalão, 30.VIII.2001, fr., L. Kollmann et al. 4442 (ESA, MBML). Vitória, Campus da UFES, 21.VIII.1986, fr., O.J. Pereira 526 (ESA, VIES).

No Espírito Santo, Trichilia tetrapetala floresce nos meses mais chuvosos do ano (novembro, dezembro e janeiro) e frutifica entre abril e outubro. Essa espécie pode ser distinta por apresentar o par de folíolos basais menores e com formato diferente dos demais $(2-13 \times$ 3-9 mm, clavados, ovoides a largo elípticos, com base extremamente assimétrica), além das inflorescências e frutos com tamanhos reduzidos.

\subsection{Trichilia sp. 1}

Árvores, 3-6 m de altura, gemas terminais sem catafilos, estrigosas a pubescentes, ramos jovens pubérulos, amadurecendo glabros. Folhas trifolioladas raramente conjuntamente com folhas unifolioladas, 8-25 cm compr., pecíolo 1,5-5 cm compr., achatado a cilíndrico, glabro a esparsamente pubérulo, sem projeções, raque cilíndrica, folíolos basais similares ao apical, peciólulos 3-15 mm compr., canaliculados a achatados, glabros a esparsamente pubérulos, lâmina 4-18 × 2-7 $\mathrm{cm}$, elíptica a oblonga, ápice acuminado, base atenuada a decorrente, face abaxial glabra, face adaxial glabra, nervura principal proeminente ou impressa em ambas as faces, nervuras secundárias proeminentes na face abaxial e impressas na face adaxial, com domácias formadas por tricomas nas axilas das nervuras secundárias e pontuações e linhas translúcidas. Inflorescências axilares, determinadas, compostas, com ramificações de primeira ordem na região basal e central, ápice com flores solitárias, 2-9 cm compr., glabras a esparsamente estrigosas. Flores amarelas ou creme, pedicelo 0,5-1 mm compr., glabro ou glabrato. Cálice dialissépalo ou com sépalas unidas apenas na base, lanceoladas a elípticas, tricomas dispostos apenas nas margens ou esparsos sobre as demais partes. Corola imbricada, dialipétala, pétalas 5, 3-4 $\times 1-2 \mathrm{~mm}$, oblongas a lanceoladas, face externa densamente papilosa e esparsamente estrigosa, face interna densamente papilosa. Estames com filetes completamente unidos formando um tubo, 2-3 mm compr, face externa densamente papilosa, face interna densamente papilosa, com tricomas esparsos, ápice do tubo com lobos agudos, alternados com as anteras e menores que essas. Anteras 8-10, 0,5-1 mm compr., pubescentes. Nectário anelar unido à base do ovário ou ausente. Ovário 3-locular, com 2 óvulos colaterais em cada lóculo, densamente pubescente, estilete glabro, estigma trilobado, papiloso. Cápsulas trigonais, curtamente estipitadas, ápice agudo, 10-15 × 9-13 $\mathrm{mm}$, densamente papilosas e pubescentes, lisas, 3 valvas, reflexas, sépalas persistentes no fruto. Sementes 7-9 mm compr., elipsoide, parcialmente recoberta por um arilo.

Material examinado: Guarapari, Parque Estadual Paulo César Vinha, 14.X.1999, fl., A.M. Assis \& C.N. Fraga 732 (ESA, VIES); 29.XII.1999, fr., A.M. Assis \& M. Canal 764 (ESA, VIES); V.2000, fr., A.M. Assis 814 (ESA, VIES). Linhares, Reserva Natural Vale, aceiro com a Fazenda Batista, 9.I.2008, fl., D.A. Folli 5833 (CVRD, ESA); Estrada da Mantegueira, 22.V.1995, fr., D.A. Folli 2616 (CVRD, ESA); Estrada do Flamengo, 12.XI.2001, fl., D.A. Folli 4115 (CVRD, ESA, RB); 29.I.2002, fr., $T$. Lazzarini 4 (CVRD, ESA).

Espécie de pequeno porte que ocorre em áreas arenosas nas florestas do Espírito Santo. Foram encontrados espécimes com flores entre 
os meses de outubro e janeiro, e com frutos no período de dezembro a janeiro e em maio. $\mathrm{O}$ reconhecimento dessa espécie é realizado por suas folhas geralmente trifolioladas ou ainda raramente em conjunto com folhas unifolioladas, pontuações translúcidas evidentes, flores com pétalas imbricadas e ovário densamente pubescente. Essa espécie é correlacionada com outras três: $T$. casaretti (folhas 3-7 folíolos, pontuações e estrias translúcidas ausentes ou de difícil visualização, ovário glabro), T. elegans (folhas com 3-9 folíolos e ovário glabro) e $T$. pallens (folhas 5-9 folíolos, pontuações e estrias translúcidas pouco evidentes e ovário glabro).

\subsection{Trichilia sp. 2}

Árvores, 20-25 m de altura, gemas terminais sem catafilos, densamente pubescentes, ramos jovens pubérulos, amadurecendo glabros. Folhas imparipinadas, 5-19 cm compr., pecíolo 1-6 mm compr., achatado a canaliculado, pubescente, sem projeções laterais, raque achatada a cilíndrica, com tricomas muito esparsos. Folíolos 3-7, além 2 ou 3 pares basais muito menores e com formato muito diferente dos demais $(2-25 \times 2-15 \mathrm{~mm}$, lineares a elípticos, base fortemente assimétrica), alternos ou opostos, peciólulo 3-17 mm compr., canaliculado, glabro a esparsamente pubescente, lâmina 5-10 $\times 2-4,5 \mathrm{~cm}$, elíptica a lanceolada, ápice agudo a acuminado, base atenuada, frequentemente assimétrica, face abaxial glabrata com tricomas sobre as nervuras, face adaxial glabra, nervura principal proeminente em ambas as faces, nervuras secundárias proeminentes em ambas as faces, sem domácias e pontuações e estrias translúcidas presentes apenas nos folíolos jovens. Inflorescências axilares, determinadas, compostas, com ramificações de primeira e segunda ordem na região basal e central, ápice com flores solitárias, 5-10 cm compr., esparsamente pubérulas. Flores alvas, pedicelo 1-2 mm compr., glabro ou com tricomas muito esparsos. Cálice gamossépalo, subemisférico, com lobos agudos, com tricomas muito esparsos. Corola valvar, dialipétala, pétalas 4-5, 3-4 × 1-2 mm, lanceoladas a oblongas, face externa densamente papilosa e esparsamente estrigosa, face interna densamente papilosa. Estames com filetes completamente unidos formando um tubo 2-3 mm compr., face externa densamente papilosa e esparsamente pubérula, face interna densamente papilosa, com tricomas longos e irregularmente orientados, ápice do tubo com lobos agudos, alternos as anteras e muito menores que essas. Anteras 8-9, 0,5-1 mm compr., densamente papilosas e pubescentes. Nectário ausente. Ovário 3-locular, com 2 óvulos colaterais em cada lóculo, densamente pubescente, estilete glabro, estigma trilobado, papiloso. Cápsulas oblongas a elipsoides, base truncada, ápice agudo, 15-22 × 7-10 $\mathrm{mm}$, densamente papilosas e pubescentes, lisas a verrucosas, 3 valvas, reflexas, sépalas não persistentes no fruto. Sementes 12-15 mm compr., elipsoides, completamente recobertas por um arilo.

Material selecionado: Linhares, Reserva Florestal da CVRD, Estrada Baba de Boi, 29.IX.1986, fl., D.A. Folli 616 (CVRD, ESA, RB); Estrada Bicuiba, ant. 162, lado esquerdo, 11.XII.1980, fl., D.A. Folli 302/80 (CVRD); Estrada Farinha Seca, 17.I.2005, fr., G.S. Siqueira 158 (CVRD, ESA); Peroba Osso, 16.I.2004, fr., D.A. Folli 4735 (CVRD, ESA, NY).

Essa espécie é encontrada exclusivamente nas Florestas de Tabuleiro da região de Linhares e são árvores de grande porte. Foi coletada com flores no final do segundo semestre do ano e frutos no começo do ano seguinte. Apresenta 2-3 pares de folíolos na base da folha com tamanhos e formatos diferentes dos demais, o que auxilia na sua identificação. É relacionada morfologicamente a Trichilia pleeana (A. Juss.) C. DC., espécie que ocorre principalmente na região amazônica. Essas espécies podem ser diferenciadas pelos frutos densamente papilosos e pubescentes em $T$. sp. 2 e glabros em T. pleeana.

\section{Agradecimentos}

À CAPES, a bolsa de Mestrado concedida ao primeiro autor; à FAPESP (Processos 2012/009647, 2014/18002-2 e 2015/09444-4). À Reserva Natural Vale, o apoio nas atividades de campo. A Gabriel Dalla Colletta, Karinne Sampaio Valdemarin e Cássio Toledo, as sugestões e comentários. Aos curadores dos herbários citados, às instituições UNICAMP, ESALQ/USP, bem como a todos os pesquisadores e técnicos que auxiliaram nesse trabalho.

\section{Referências}

Bergamaschi RB \& França CJ (2011) Espírito Santo em mapas. $3^{\text {a }}$ ed. Instituto Jones dos Santos Neves, Vitória. 97p.

BFG - The Brazil Flora Group (2015) Growing knowledge: an overview of seed plant diversity in Brazil. Rodriguésia 66: 1085-1113.

Candolle AP (1824) Prodromus systematis naturalis Regni Vegetabilis 1: 619-626. 
Candolle C (1878a) Meliaceae. In: Martius CFP \& Eichler AG (eds.) Flora brasiliensis. Frid. Fleischer, Lipsiae. Vol. 11, pars 1, tab. 50-65, pp. 165-228.

Candolle C (1878b) Meliaceae. In: Candolle A \& Candolle C. Monographiae Phanerogamarum 1: 419-758.

Filho PG, Peixoto AL \& Jesus RM (2000) Espécies vegetais descritas a partir de espécimes coletados na Reserva Florestal de Linhares, Espírito Santo, Brasil. Boletim do Museu de Biologia Mello Leitão 11/12: 35-48.

Font Quer P (1953) Dicionario de Botanica. Ed. Labor, Barcelona. 1244p.

Fundação SOS Mata Atlântica, Instituto Nacional de Pesquisas Espaciais (INPE) \& Instituto Sócio ambiental (ISA) (1993) Atlas da evolução dos remanescentes florestais e ecossistemas associados no domínio da Mata Atlântica no período 19851990. Relatório técnico. Fundação SOS Mata Atlântica, São Paulo. 60p.

Gadek PA, Fernando ES, Quinn CJ, Hoot SB, Terrazas T, Sheahan MC \& Chase MW (1996) Sapindales: molecular delimitation and infraordinal groups. American Journal of Botany 83: 802-811.

Garbin, ML, Saiter, FZ, Carrijo TT \& Peixoto AL (2017) Breve histórico e classificação da vegetação capixaba. Rodriguésia 68: 1883-1894.

Gentry AH (1988) Changes in plant community diversity and floristic composition on environmental and geographical gradients. Annals of the Missouri Botanical Garden 75: 1-34.

Harms H (1896) Meliaceae. In: Engler A \& Prantl K. Die Natürlichen Pflanzenfamilien. 3: 258-308.

Harms H (1940) Meliaceae. In: Engler A \& Prantl K. 2a ed. Die Natürlichen Pflanzenfamilien. 19bl: 1-172.

Harris JG \& Harris MW (1995) Plant Identification Terminology: an illustrated glossary. Missouri Botanical Garden Library, Saint Louis. 206p.

Hickey LJ (1973) Classification of the Architecture of Dycotyledoneous Leaves. American Journal of Botany 1: 17-33.

Hooker JD (1862) Meliaceae. In: Bentham G \& Hooker JD. Genera Plantarum I: 327-340.

IPEMA (2005) Conservação da Mata Atlântica no estado do Espírito Santo: cobertura florestal e unidades de conservação. IPEMA, Vitória. 142p.
Kenfack D (2011) A synoptic revision of Carapa (Meliaceae). Harvard Paper in Botany 16: 171-231.

Lorenzi H, Souza HM, Torres MAV \& Bacher LB (2003) Árvores exóticas no Brasil - madeireiras, ornamentais e aromáticas. Ed. Plantarum, Nova Odessa. 385p.

Mabberley DJ, Pannell CM \& Sing AM (1995) Meliaceae. Flora Malesiana, Ser. 1, Spermat. 12: 1-407.

Muellner AN, Samuel R, Johnson SA, Cheek M, Pennington TD \& Chase MW (2003) Molecular Phylogenetics of Meliaceae based on nuclear and plastid DNA sequences. American Journal of Botany 90: 417-480.

Muellner AN, Vassiliades DD \& Renner SS (2007) Placing Biebersteiniaceae, a herbaceous clade of Sapindales, in a temporal and geographic context. Plant Systematics and Evolution 266: 233-252.

Payne WW (1978) A glossary of plant hair terminology. Vol. 2. Brittonia 30: 239-255.

Pennington TD \& Styles BT (1975) A generic monograph of the Meliaceae. Blumea 22: 419-540.

Pennington TD (1981) Meliaceae. Flora Neotropica 28: 1-470.

Pennington TD \& Muellner AN (2010) A monograph of Cedrela (Meliaceae). Ed. dh books. Milborne Port. 112p.

Pennington TD \& Clarkson JJ (2013) A revision of Guarea (Meliaceae). Edinburgh Journal of Botany 70: 179-362.

Pennington TD (2016) Systematic treatment of American Trichilia (Meliaceae). Phytotaxa 259: 18-162.

Radford AE, Dickinson WC, Massey JR \& Bell CR (1974) Vascular plant systematics. Harper \& Row Pub., New York. 891p.

Simonelli M \& Fraga CN (2007) Espécies da flora ameaçada de extinção no estado do Espírito Santo. Ed. Ipanema, Vitória. 143p.

Souza VC \& Lorenzi H (2010) Botânica sistemática guia ilustrado para identificação das famílias de Fanerógamas nativas e exóticas no Brasil, baseado em APG III. 3a ed. Plantarum, Nova Odessa. 768p.

Thiers B [continuamente atualizado]. Index Herbariorum: a global directory of public herbaria and associated staff. New York Botanical Garden's Virtual Herbarium. Disponível em $<$ http://sweetgum.nybg. org/science/ih/> . Acesso em 17 de Outubro de 2016. 
